\title{
O Valor e suas Formas na Crítica MarXiana da Economia Política ${ }^{1}$
}

\author{
Antonio Jose Lopes Alves ${ }^{2}$
}

\begin{abstract}
RESUMO: No presente artigo, propóe-se apresentar e explicitar o estatuto teórico da categoria marxiana do valor, conforme determinado no contexto da crítica da economia política, em sua fase madura (1857-1881). Em especial, pretende-se discutir o modo como Marx aborda a relação da determinação categorial do valor com as demais que compóem e constituem a forma mercadoria dos produtos do trabalho humano. Nesse sentido, a teoria marxiana do valor aparece como exposiçáo crítica do modo de produção capitalista a partir da análise categorial da mercadoria, tendo como meta revelá-la na sua dimensão mais essencial: a de veículo de realização da valorizaçáo do valor. A forma valor, acompanhando o desenvolvimento da argumentaçấo marxiana em Grundrisse e $O$ Capital, é analisada em sua configuração de determinação em processo, que se desdobra, pressupôe e implica um conjunto de outras Formen que se articulam em momentos de diferenciação e desenvolvimento reais que se expressam concretamente nas objetivaçôes do trabalho humano existindo como momentos do capital. Mercadoria, mercado e capital perdem todos sua aparência de exterioridade recíproca de "coisas" para se desvelarem realizaçóes de um modo sócio-histórico de produzir a vida humana.
\end{abstract}

PALAVRAS-CHAVE: Marx. Crítica da Economia Política. Valor. Capital. Categoria.

\section{I}

\section{A Forma Mercadoria como Unidade do Diverso}

Em um dos seus últimos escritos, Glosas Marginais ao Tratado de Economia Política de Adolph Wagner, Marx observa que, “[...] nem o 'o valor' nem o 'valor de troca' são para mim o sujeito, mas a mercadoria $\{\mathrm{da} \beta$ weder 'der Wert', noch, 'der Tauschwert' bei mir Subjekte sind, sondern die Ware\}." (MARX, 1962, p. 358). Nesse sentido, a analítica marxiana não tem por ponto de partida uma categoria abstratamente posta, como pura figura conceitual ou epistêmica, porém, uma entificação dada e concreta, particular, a mercadoria. Assim, a recusa de figuras abstrativas puras como fundamento teórico póe como arrimo e metro da análise levada a efeito o próprio concreto examinado, e como telos desse mesmo esforço de intelecção a dilucidação dos nexos essenciais e

\footnotetext{
${ }^{1}$ http://dx.doi.org/10.1590/S0101-31732016000100009

2 Professor da UFMG, Doutor em Filosofia, Membro do Grupo de Pesquisa Marxologia: Filosofia e Estudos Confluentes CNPq, e-mail: ajlopesalves@gmail.com.
} 
dos principais aspectos que perfazem o objeto como tal. No caso em questão, a mercadoria assim como ela se dá, em seu Dasein, nas formas mais imediatas da sociabilidade do capital, e a sua Daseinform social específica que a delimita como a forma de aparição da riqueza correspondente ao modo de produção capitalista. O sujeito real da analítica marxiana não é então um conceito, uma ideia ou categoria como ser do puro pensar ou produto da uma posição metodológica previamente delineada. Ao contrário, trata-se sempre do factum da coisa efetiva, em sua existência concreta e objetiva, na imanência das formas de ser que a determinam. A teorização arranca dessa maneira, daquilo que Marx denomina Konkretum der Ware (MARX, 1962, p. 369), do concretum da mercadoria, de uma dada forma objetiva de entificação da riqueza, bem característica ao capital, o que delimita a figuração mesma da mercadoria na modernidade como uma forma de existência particular que se distingue dos objetos das simples trocas mercantis, as quais existiram e vigoraram em modos societários de intercâmbios anteriores à circulação propriamente capitalista.

Além disso, é instrutivo notar que, no movimento de exame crítico, Marx, ao mesmo tempo em que indica as principais lacunas ou fragilidades que, a seu ver, caracterizam a posição de Wagner, cuida de explicitar com mais detalhamento os pressupostos ou pontos principais de sua própria teorização. Desse modo, da questáo do que constitui a análise da forma mercadoria, empreendida no Livro I de O Capital, até as consideraçóes sobre os problemas relativos à circulação, passando, obviamente, pelo espinhosa querela da substância do valor, os principais complexos categoriais tratados na crítica da economia política aparecem nas glosas a Wagner. E não apenas isso, aparece também no escrito em tela a retomada de seus posicionamentos críticos acerca da especulação filosófica, a qual substancializava as categorias, transformandoas em formas ideais puras e autônomas, dotadas de estatuto de realidade concreta, cujo movimento de determinação se expressaria teoricamente, como cerne racional da efetividade objetiva como tal. Essa coisa se realiza em Wagner naquilo que Marx chama jocosamente de economia de conceitos (Begriffswirtschaff) (MARX, 1962, p. 364). Uma modalidade de raciocínio, a wirtschaff, não tanto científica (como o seria a Ökonomie), mas, na melhor das hipóteses, pragmática, contábil, manipuladora de valores, de teres e haveres. Não se estaria mais no terreno da compreensão determinativa da produção da reprodução conceitual dos circuitos que a integram - senão da apreensão de conexôes operacionais imediatas das figuras do cômputo cotidiano e pedestre do tráfico ordinário. A força irônica se amplia, na medida em que a delimitação crítica de Marx apóe àquela a remissão ao conceito, o que afasta a elaboração 
wagneriana inclusive da efetividade ao menos empírica que caracteriza a aproximação contábil dos fenômenos econômicos. Wagner uniria assim o pior de dois mundos... De um lado, o comportamento manipulador da prática fenomênica imediata, típica dos mascates e, de outro lado, a idiossincrasia própria aos professores alemães, engendradores de sistemas conceituais puros.

Ao afastamento da Begriffswirtschaff wagneriana corresponde o empreendimento teorético de capturar a trama constituinte da efetividade da forma burguesa da produção, tendo como base não um dado método, dialético ou coisa que o valha, o qual teria o apanágio de facultar ao seu possuidor o acesso seguro à verdade da coisa, mas o reconhecimento inicial necessário da efetividade do existente. Como quem escarafuncha um terreno ou um material dado, destarte, no exercício de uma analítica rigorosa e minuciosa, Marx desenha um roteiro de escavação progressiva do objeto, com o fito de adentrar em seu âmago determinativo. Não por outro motivo, Marx escolherá o termo ergründen, literalmente penetrar, para expor ao leitor, no prefácio à primeira ediçáo de $O$ Capital, a tarefa a que se destina sua teoria, o desvendamento da forma valor, o coração mesmo da mercadoria. Nesse diapasão, no entanto, a reflexão científica marxiana não pode ter como início o enfrentamento da categoria valor em seu isolamento conceitual, arriscando cair ou bem numa mera dialética de formas puras do pensamento ou bem numa elucubração linguística, que se resume, na melhor das hipóteses, a volteios intelectuais entorno da significação de termos. Nas duas opções, faces de um modus filosófico cuja démarche, conquanto diferenças de sofisticação e competência, pertence a um idêntico padrão cognitivo. A especulação, em suas versốes sofisticada ou simplória, tem como resultante necessária a perda das determinaçóes reais e objetivas dos fenômenos em benefício de um jogo reflexivo. Marxianamente, a logicidade maior ou menor de uma elaboração de semelhante talhe em nada altera a sua configuração problemática. Por essa razão, assevera em primeira pessoa, de maneira vigorosa:

Eu nunca falo da "substância social comum do valor de troca", digo antes que os valores de troca (valor de troca sem ao menos dois, não existe) representam alguma coisa comum a eles, que é de todo independente de "seus valores de uso" (isto é, aqui, de sua forma natural), saber, o "valor". (MARX, 1962, p. 358, grifo do autor).

Ou seja, o valor, como categoria do real - e é disso sempre que se tratará, em Marx, como o veremos - não existe a não ser como esse elemento comum a duas mercadorias, que se expressará, figurativamente no intercâmbio empírico, como um terceiro no confronto das mesmas. Se, de uma parte, a 
penetração cognitiva da categoria valor é o alvo, seu esclarecimento científico, de outra, forçosamente, a consecução desse telos somente pode realizar-se na medida em que o discurso não perca de vista a natureza própria de aspecto que o define; ser apenas determinação. $\mathrm{Na}$ ausência de tal cuidado analítico, facilmente se recai na especulatividade própria aos discursos que invertem a ordem de ser entre categoria ou forma e os objetos concretos. No âmbito da especulação, faz-se dos segundos meros modos de ser fenomênicos da primeira. A determinação passa assim a apresentar-se como sujeito real e não como momento essencial de um sujeito real. A differentia specifica da analítica se patenteia porquanto seja seu ponto de partida - necessário e irredutível -, o concreto, mais que simples pretexto para o desenvolvimento lógico de uma trama conceitual. Contrariamente, o ente/processo continua a existir como parâmetro aquém e independente da forma epistêmica de confrontá-lo. A investigação, portanto, tem, por isso, seu ponto de partida precisamente na analítica da mercadoria, a Elementarform da riqueza na sociabilidade do capital. O início é a forma na qual o resultado da produção humana aparece imediatamente, e à maneira da pluralidade de seus produtos: "A riqueza das sociedades nas quais domina o modo de produção capitalista aparece como uma 'imensa coleção de mercadorias', a mercadoria individual como sua forma elementar \{Elementarform\}.” (MARX, 1998, p. 49). A investigação parte aqui da mercadoria, a forma elementar, conforme esta se apresenta, para revelar-lhe o conjunto das determinaçóes que a constituem como tal, procedimento o qual, ao contrário daquele dos economistas que iniciam pela produção em geral ou pelo dinheiro, afirma o momento concreto como metro da cientificidade.

Dizer-se da mercadoria uma forma elementar pode ser entendida num duplo sentido. Seja como unidade simples e imediata do produto do trabalho na vigência do capital, na sua acepção mais direta e, aparentemente, isenta de pressuposiçóes. Mas, igualmente, enquanto seja simultaneamente a modalidade de existência necessária que todos os resultados da produção humana têm de revestir-se para poderem alcançar a esfera de sua plena sociabilização, a fim de, por assim dizer, lograr vida social.

Nesse contexto, a primeira determinação a ser explicitada por Marx é aquela que se oferece imediatamente à intuição e à representação dos sujeitos da circulação simples e do consumo, o valor de uso. Ou seja, é ela

[...] um objeto externo, uma coisa, que por suas propriedades satisfaz necessidades humanas de qualquer tipo. A natureza dessas necessidades, se elas se originam, por exemplo, do estômago ou da fantasia, nada altera 
a coisa. Não se trata aqui também de como a coisa satisfaz a necessidade humana, seja imediatamente, como meio de subsistência, isto é, como objeto da fruição \{Gegenstand des Genusses\}, ou sob uma via indireta, como meio de produção. (MARX, 1998, p. 49).

Como valor de uso, a mercadoria é außere Gegenstand, uma figura de exterioridade plena, existente por-si e possuidora de elementos ou caracteres que a qualificam como objeto particular, determinado, ainda que socialmente posto (à diferença dos objetos ou entes naturais). Para além da aparente obviedade contida na afirmação da mercadoria como eine Ding, uma coisa, explicita-se o princípio científico-filosófico que dá o parâmetro ao discurso marxiano: a identificação, e o consequente respeito, teóricos pelo caráter de ente do próprio objeto investigado. Por ter em si certos traços concretos, imanentes, "naturais", a mercadoria satisfaz necessidades humanas de qualquer tipo. A utilidade da mercadoria, a qual decorre de seu valor de uso, é determinada pelas propriedades do corpo da mercadoria (Warenkorps). Desse modo, "[e] sse seu caráter não depende de se a apropriação de suas propriedades úteis custa mais ou menos trabalho ao homem.” (MARX, 1998, p.50), é uma determinação cuja imediatidade se afirma tão logo o trabalho humano se objetive na forma de um produto qualquer. Entretanto, se, por esse viés, é esse caráter um lado mais empírico e imediato, por outro lado, é ele produto da atividade concreta dos homens, seja aquela de criação de coisas úteis, seja a da descoberta e fixação da serventia que os objetos encontrados na natureza possam ter. De toda maneira, é a objetivação um ato histórico (geschichtliche Tat) (MARX, 1998, p. 50). Assim, o caráter de ser da mercadoria, sua natureza de ente concreto, remete também à qualidade de entificação histórico-social, o que não anula, nem no momento da produçáo nem naquele do consumo, a imanência das determinaçóes da mercadoria como valor de uso, mas as particulariza como posição histórica e societária dos homens na resposta às demandas colocadas pelos diversos carecimentos oriundos das diversas necessidades de sobrevivência. A esse respeito, vale aqui notar que, num outro momento de sua vida intelectual, o qual pode ser situado como o de constituição do padrão reflexivo marxiano, em A Ideologia Alemã, observa-se: "O primeiro pressuposto de toda história humana é naturalmente a existência de indivíduos humanos vivos." (MARX; ENGELS, 1969, p.20). Na sequência, dá o passo teórico fundamental, ao afirmar que, diversamente do que ocorre entre os animais, as condiçôes de vida desses mesmos indivíduos sociais são produtos de sua atividade concreta de criação de meios de existência. Culmina, numa passagem suprimida do manuscrito, com a enunciação de que "[o] 
primeiro ato histórico destes indivíduos, pelo qual se distinguem dos animais, não é o fato de pensar, mas o de produzirem seus meios de vida \{Lebensmittel zu produzieren\}." (MARX; ENGELS, 1969, p. 20).

O valor de uso assim não deve ser compreendido como naturalidade, num sentido de absolutamente não social, não obstante o próprio Marx se utilize desse vocábulo para distingui-lo do valor, a determinação puramente social da mercadoria. Muito ao contrário, natural aparece aqui como indicativo de imanência à mercadoria como produto de atividade concreta e útil. O valor de uso, longe de uma pretensa naturalidade, de teor físicobiológico, a qual the pode ser atribuída pela aparência das afirmaçóes marxianas, é um algo posto pelo haver-se social prático-concreto, efetivo, com a mundaneidade - haver-se o qual é ele mesmo ato social. A utilidade depende das características objetivas, imanentes, inerentes, "naturais" das coisas, mas aquelas são resultantes, igualmente objetivas e materiais, da prática concreta dos homens, de sua produção. $\mathrm{O}$ valor de uso, assim sendo, independe, em sua delimitação categorial, da quantidade de trabalho despendido em sua produção, da apropriaçáo do mundo numa forma humana, não obstante também possua uma determinidade quantitativa, sua qualidade de objetos discretos e singulares. A determinidade aqui aludida é definida, em termos de sua medida, pelos aspectos específicos de cada tipo de valor de uso, de sua quantidade unitária, do modo como suas características particulares podem ser medidas, agrupadas e separadas. Em virtude disso, Marx delimitará o valor de uso como "[...] o conteúdo material da riqueza, qualquer que seja sua forma social. $\mathrm{Na}$ forma de sociedade a ser considerada elas constituem, ao mesmo tempo, os portadores materiais do valor de troca (die stofflichen Träger desTauschswerts)." (MARX, 1998, p.50). Conteúdo concreto da riqueza que, por força do tipo específico de sociabilidade, a do capital, à qual a análise marxiana se dirige, tem adensado à sua particularidade de produto do trabalho, outra cuja origem radica na forma social da produçáo. Em outros termos, ser valor de troca, ou simplesmente valor, não é resultante do ato social de objetivação dos homens frente à necessidade de se produzirem, mas é um aspecto que remete a um dado estádio histórico da sua produção. Ser valor e capital não são qualidades imanentes às mercadorias como produtos da atividade produtiva sans phrase, contudo, são elementos determinativos relativos ao modo como as categorias sociais vigem e são organizadas num momento histórico bem preciso e delimitado. Propriedade histórico-social que emerge e delimita a mercadoria como forma material de uma dada relação social, o valor de troca. Tornarse stofflichen Träger des-Tauschswerts não é uma destinação ou uma fatalidade 
inscrita à testa da mercadoria como objetivação, mas forma de ser que converte o ser produzido simplesmente para outrem em para outrem na mediação e vigência do valor, sob o mando absoluto da necessidade de reprodução do capital. Tal determinação torna densas as aparentemente calmas águas da mercadoria, a ponto de turvá-las mesmo, elaborando-as como signos do valor.

A segunda determinação que emerge no exercício da analítica da mercadoria, partindo de sua figura mais fenomênica, é aquela que se dá imediatamente como valor de troca. E a esse respeito é importante ressaltar a observação marxiana, feita contra Wagner, de que o valor de troca não é a categoria determinadora em sua especificidade. Essa é antes melhor uma forma de aparecer dela, na medida em que apenas se tem valor de troca como pluralidade de mercadorias, no interior de uma relação que as coloca frente a frente como produtos do trabalho humano em geral. Trata-se de uma forma relacional, uma vez que valor de troca sem ao menos dois, não existe, na qual se expressa a determinação que cabe elucidar e explicitar cientificamente. Tal observação se reverte de importância central, porque discerne os âmbitos e dimensôes do escopo da investigação, ao estabelecer uma distinção entre os níveis mais fenomênicos e imediatos, e aqueles de caráter mais essencial. Sem essa distinção, ficar-se-ia às voltas com os aspectos mais quantitativos da relação de valor, não se obtendo desse modo a apreensão dos elementos que a delimitam e a determinam como tal. Por esse motivo, não é uma determinação intrínseca à mercadoria, enquanto simples produto de trabalho tomado em geral, é uma determinação, uma forma de ser, eminentemente relacional:

O valor de troca aparece, inicialmente, como a relação quantitativa, a proporçáo na qual valores de uso de um tipo se trocam por valores de uso de outro tipo, uma relação que muda constantemente com o tempo e o lugar. $\mathrm{O}$ valor de troca parece por isso como algo acidental e puramente relativo; um valor de troca imanente (valeur intrinsèque), imanente à mercadoria, portanto uma contradictio in adjecto. (MARX, 1998, p. 50-51).

Assim sendo, o valor de troca é a determinação propriamente quantitativa, na qual os valores de uso, resultantes da atividade produtiva, se intercambiam socialmente. Por essa razão, tal categoria remete de maneira direta à proporção, à medida pela qual as mercadorias são trocadas. Não sendo uma imanência à mercadoria como simples objetivação da atividade humana, o valor de troca não é ele mesmo, então, medida da relação.

Não obstante o valor de troca não ter o caráter de determinação, no que respeita à forma de ser do produto na sociabilidade do capital, sendo 
ao contrário, forma expressão, ou de aparição, Erscheinungsform, este torna possível, por outro ângulo, flagrar pela análise indícios que encaminham o exame ao momento preponderante da forma mercadoria. Nesse passo da argumentação, Marx estabelece, ainda que sucintamente, uma série de conexóes e distinçóes entre valor de uso e valor de troca, as quais permitem a aproximação categorial da determinação essencial. A primeira das relaçóes categoriais que se deve referir é o fato de que não há valor, e muito menos valores de troca, sem valor de uso, de sorte que "[...] nenhuma coisa pode ser valor $\{k a n n$ kein Ding Wertsein $\}$, sem ser objeto de uso. O que é inútil, é também inútil o trabalho nela contido, não conta como trabalho e não constitui por isso nenhum valor" (MARX, 1998, p. 50). O caráter de utilidade da coisa não apenas se constitui num suporte ao valor, mas também, com anterioridade na ordem de determinaçóes, numa condição de ser das mercadorias, o que não anula a diferença entre tais traços, todavia, ao identificar o nexo que os une, indica a tensão imanente à forma de ser mercadoria do produto. Apontamento analítico que não estanca na posse de uma identidade abstrata: muito ao contrário, exige como desenvolvimento conceitual necessário a explicitação da distinção categorial entre valor de uso e valor. Não é apenas por ter "um valor para alguém", ser útil, que tais ou quais objetos são valores:

Uma coisa pode ser valor de uso, sem ser valor. É o caso, quando sua utilidade para os homens não é mediada pelo trabalho. Assim o ar, o solo virgem, os gramados naturais, as matas selvagens etc. Uma coisa pode ser útil e produto do trabalho humano sem ser mercadoria. Quem por meio de seu produto satisfaz sua própria necessidade, cria valor de uso, mas não mercadoria. (MARX, 1998, p. 50-51).

Ou seja, ser valor, além de ser valor de uso, não é uma determinação intrínseca ao produto do trabalho ou aos objetos da atividade dados diretamente, sem mediação produtiva anterior, à produção. Algo pode muito bem ser útil, produzido ou náo, satisfazer uma necessidade humanossocietária qualquer, individual ou grupal, sem que seja apenas por isso mercadoria. Marx prossegue o movimento analítico desdobrando que, "[p]ara produzir mercadoria, ele não deve produzir apenas valor de uso, mas valor de uso para outrem, valor de uso social", o produto do trabalho deve dirigir-se, e isso é decisivo, imediatamente a outrem, visar algo mais que a satisfação da necessidade no limite individual. A mercadoria aparece como forma eminentemente social do produto, forma de ser que tem no remetimento ao outro um aspecto inextricável da própria atividade de produção, o qual a rege, dá sentido e pertinência. Náo se trata da existência da troca e do intercâmbio sociais como contingência, 
momento de exterioridade, em cuja indiferença para a produção fizesse deles simples consequência do arbítrio e/ou da carência extrema do produtor. Ao contrário, a direção, a forma e os modos da atividade se dão pela vigência necessária do commercio hominum. Entretanto, fixando-se tal determinação em sua figura imediata, como posição da produçáo como algo precipuamente voltado a outrem, corre-se o risco de tornar a forma mercadoria, forma universal da interatividade humana, o que, evidentemente, se encontra em direta contraposição com o pensamento marxiano. Nesse sentido, Marx, na sequência, vai delimitar de maneira mais rigorosa aquele remetimento a outrem. É para outrem, mas não só para outrem, simplesmente:

O camponês medieval produzia trigo para o senhor feudal, e o trigo do dízimo para o clérigo. Mas nem o trigo nem o trigo do dízimo eram por isso mercadorias, por serem produzidos para outrem. Para vir a ser mercadoria, o produto precisa vir a ser transferido a outrem, servir a outrem como valor de uso, através da troca. (MARX, 1998, p.55).

Não se trata, por isso, do gift, do presente ou do donativo, nem menos das formas de intercâmbio social anteriores ao capital. Como sempre, o que demanda a compreensão e a apreensão da coisa investigada é o desvendamento de sua particularidade, de sua differentia specifica. É a explicitação do caráter determinativo próprio à mercadoria que vai encaminhar a análise para além dessa forma relacional imediata. No seu desdobrar-se, o exame revela ser o valor de troca uma determinação de caráter ainda puramente fenomenal.

O valor de troca, por dizer-se sempre no plural, como determinação relativa, pertence à ordem da multiplicidade e da multilateralidade de intercâmbios que perfazem o conjunto do mundo das mercadorias. Náo obstante isso, como mais acima se afirmou, o valor de troca aponta para um elemento que vige na própria relação, que dá a essa seu parâmetro, e é por ela realizado:

Tomemos ainda duas mercadorias, por exemplo, trigo e ferro. Qualquer que seja sua relação de troca, ela é sempre apresentável \{darstellbar\} em uma equação na qual dado quantum de trigo vem a ser igualado a dado quantum de ferro, por exemplo, 1 quarter de trigo = z quintais de ferro. $\mathrm{O}$ que diz essa equação? Que um algo comum de mesma grandeza existe em duas coisas diferentes, em 1 quarter de trigo e, igualmente, em z quintais de ferro. Ambas são, portanto, iguais a um terceiro, o que em si e para si não é nem um nem outro. Cada um dos dois, enquanto seja valor de troca, deve ser, portanto, redutível \{reduzierbar\} ao terceiro \{auf dies Dritte\}. (MARX, 1998, p.51). 
A existência de um igual ao qual as mercadorias são equiparadas, um terceiro (Dritte), que como medium realiza a unidade das próprias relaçóes de troca, pondo-as em equação, faz surgir em cena o valor propriamente dito. Ao mesmo tempo, delimita o valor de uso, em consequência, como um signo no qual aquele elemento equacional se exprime como relação das mercadorias umas com as outras. Assim, o valor de troca é tão somente "modo de expressáo" (Ausdrucksweise) ou "forma de aparição" (Erscheinungsform) daquele terceiro, com o qual não se identifica, mas efetiva a relação proporcional (Verhältnis) na função social de medida dos produtos do trabalho postos como valores (MARX, 1998, p. 51); é o terceiro elemento da relação proporcionalmente efetivada entre as mercadorias, o qual se constituirá então no objeto propriamente dito da analítica. Presença preponderante na relação é exatamente esse Gemeinsames, algo comum, o valor, que constitui o übergreifendes da forma mercadoria, do qual o valor de troca é fenômeno. Dessa maneira, o ato da troca, o qual constitui um ato de equiparaçáo, onde $\mathrm{x}$ de um dado tipo de mercadoria = y duma outra de tipo diverso, afirma a existência de uma identidade na e pela múltipla diversidade dos valores,uma forma objetiva que se póe, ao mesmo tempo, como aquilo que de comum determina os valores e deles difere efetivamente. As trocas proporcionais entre valores de tipos variados apontam para o valor, para o terceiro ao qual aqueles são realmente reduzidos.

\section{II}

\section{O Valor como Determinaçáo}

Entretanto, qual seria a natureza desse Gemeinsames a que os valores, em sua diversidade, são reduzidos? Em primeiro lugar, é uma coisa completamente diferente das propriedades "naturais" das mercadorias, tomadas como valores de uso, dos aspectos objetivos imanentes àquelas como produtos de trabalho útil e particular, suas características concretas, que lhes conferem utilidade. É, ao contrário, exatamente a abstração (Abstraktion) dessas propriedades que constitui, negativamente, o valor. Tal característica não radica no valor de uso: "Como valores de uso, as mercadorias são todas de diferente qualidade, como valor de troca somente podem ser de quantidade diferente, não contêm, portanto nenhum átomo de valor de uso" (MARX, 1998, p.52). Nessa determinação abstrata, já que ela se póe pela negaçáo da concretude dos valores de troca, bem como dos trabalhos úteis e concretos que os produzem, resta tão somente a qualidade das mercadorias, a de serem "produtos de trabalho" (Arbesitsprodukten). Marx, por isso, observa: 
Afastado o valor de uso do corpo das mercadorias, vejam que resta ainda apenas uma propriedade, a de produtos do trabalho. No entanto, o produto do trabalho já se transformou em nossas mãos. Abstraindo de seus valores de uso, abstraem-se assim também de seus elementos constituintes materiais e formais, que faz dela valor de uso. Não permanece mesa ou casa ou fio ou uma outra coisa útil. Todas as suas qualidades sensíveis \{sinnlichen\} estấo apagadas. Não permanece produto do marceneiro ou do pedreiro ou do fiandeiro ou de outro trabalho produtivo. Com o caráter útil do trabalho produtivo desaparece o caráter útil dos trabalhos nela apresentados, desaparece por isso também as diferentes formas desses trabalhos, eles não se diferenciam mais, mas são na totalidade reduzidos a trabalho humano igual, a trabalho humano abstrato. (MARX, 1998, p. 52).

Assim como, com o valor de troca, desaparece (verschwindet) o caráter útil dos produtos, igualmente se apaga esse traço da própria atividade que os cria. A equiparação das coisas como mercadorias, na forma de objetos sociais precipuamente produzidos para outrem na mediação da troca, revela o cunho próprio da atividade mesma que as faz existir. Para além, para aquém, da aparência imediata do intercâmbio, onde o aparecer da determinação afirma a variedade inescapável dos valores, a momento determinador da relação, ao contrário, infirma a multiplicidade, ao colocá-la sob a égide de um elemento que nega a própria diversidade das mercadorias. Com a infirmação dessa característica das trocas se apaga igualmente aquela das atividades que criam as coisas trocadas. Do mesmo modo que o valor é a forma da anulação da diversidade e especificidade dos produtos, ele o é para a produçáo, em seus mais diferentes ramos. A sociabilidade da atividade, ou o caráter social do trabalho aparece como abstração das formas concretas e úteis da produção humana, convertendo-se num mero medium abstrato, na medida do valor dos produtos. Da determinação do valor, emerge outra, aquela do trabalho abstrato.

Despidos da sua forma "natural", o que persiste então da concretude dos produtos? Continua Marx (, 1998, p. 52), afirmando:

Não restou nele senão a objetividade fantasmagórica (gespenstige Gegenständlichkeit), uma simples gelatina de trabalho humano indiferenciado, isto é o dispêndio de força de trabalho humana sem consideração acerca da forma de dispêndio dela. Essas coisas representam ainda apenas que em sua produçáo foi gasto força de trabalho humana, foi acumulado trabalho humano. Como cristais dessa sua substância social comum, são elas mercadorias - valores mercadorias.

Daí as coisas produzidas existirem nos contornos do capital, antes de tudo, como "valores", "elas são valores" (sind sie Werte). As mercadorias indicam 
agora apenas que, em sua criação, foi despendido trabalho humano, in abstracto, em geral, indiferenciado; sua forma de existência social, mercadoria, traz à tona, no ato de realização de seu fim, a troca, a determinação do valor, como seu momento essencial de vigência real. Forma de ser social, pois que, em primeiro lugar, é base de um modo de existir recebida nos quadros delimitados por um tipo particular de sociabilidade, aquela do capital. E, em segundo lugar, e mais decisivo ainda, é afirmação do caráter social, geral, do próprio trabalho humano, náo obstante pela via contraditória da negação necessária das modalidades concretas da própria atividade. Nesse sentido, o valor é uma abstração real. Não é gerada por procedimentos da troca (menos ainda como conteúdo pura da consciência), mas nestes, na sua efetuação, ao contrário, o expressam e o valor de troca como notwendigen Ausdrucksweise oder Erscheinungsform des Wert:

$\mathrm{Na}$ própria relação de troca das mercadorias aparece-nos o valor de troca destas como algo de indiferente a seus valores de uso. Abstraindose entáo, efetivamente, do valor de uso dos produtos do trabalho, assim obtém seu valor, como ele, agora a pouco, foi determinado. O comum que se apresenta na relação de troca ou valor de troca é, portanto, seu valor (MARX, 1998, p.53).

Em outro momento de elaboração da teoria do valor, um pouco anterior, situado nos Grundrisse, também se pode encontrar um exercício analítico próximo, não obstante as diferenças de natureza bibliográfica e de ponto de partida. O discurso marxiano, no que tange à delimitação conceitual da categoria valor, segue aqui um rumo diverso, arranca da relação entre valor e preço, mercadoria e dinheiro.

O valor aparece, por conseguinte, como determinação central das mercadorias em relaçáo aos preços. $\mathrm{O}$ preço se diferencia do valor náo somente como o nominal se distingue do real, não somente por sua denominação em ouro e prata, mas porque o valor aparece como a lei (Gesetz) dos movimentos descritos pelo dinheiro. Constitui determinação essencial que não é resultado de uma "redução" subjetiva, no entanto, é e existe efetivamente por via de sua forma de aparecer, não obstante diferente e quase nunca coincidente com esta, a expressão de valor. Expressão de valor que se efetiva como realidade das trocas múltiplas de mercadorias, nas quais o preço exprime, num abaixo ou acima do valor, fenomenicamente, a medida dada pela forma social preponderante: "A diferença entre preço e valor, entre a mercadoria, medida pelo tempo de trabalho no qual ela é produzida e o produto do tempo de trabalho pelo qual ela se troca, esta diferença exige uma terceira mercadoria por medida, na qual se exprima 
o valor de troca efetivo da mercadoria”. Movimento de expressão pelo qual o valor se exprime idealmente nos preços das mercadorias, delimita num sentido bastante complexo a relação entre determinação essencial e formas fenomênicas, de sorte que entre as primeiras e as segundas não vige a univocidade de uma deduçáo de princípio, nem o funcionamento de alguma ordenação categorial hierárquica em termos absolutos. Medeia entre os dois momentos uma articulação que supera aquela de causação dum efeito ou de atualização essencial. O que Marx delimita teoricamente é uma forma de expressão aparente, mas real, imediata, não obstante propriamente concreta. $\mathrm{O}$ valor é expressado naquelas formas que aparecem e tomam parte no circuito efetivo de reproduçáo social - expressão, nota bene, não identidade, entre o valor e suas formas de aparecer. A posiçáo do valor na efetividade das trocas se dá mediante o preço, todavia, permanece a diferença fundamental entre os dois níveis da coisa-expressão que envolve, ao mesmo tempo, identidade e não identidade reais e simultâneas, por que não aqui, "dialéticas". Assim, continua Marx (1983, p. 75):

Porque o preço não é igual ao valor, o elemento que determina o valor - o tempo de trabalho - não pode ser o elemento no qual se exprimem os preços, porque o tempo de trabalho deveria exprimir-se simultaneamente como elemento determinante e não determinante, como iguale desigual a si mesmo. Porque o tempo de trabalho, como medida de valor, existe apenas idealmente \{nur ideal existiert\}, não pode servir de material de comparação dos preços. (Grifo nosso)

Exercitação analítica de comparável teor pode ser também observada no tratamento marxiano das relaçóes entre mercadoria e dinheiro. O dinheiro, diferentemente do que uma posição positivista poderia supor, tem também sua gênese, a qual se situa no próprio quiproquó das mercadorias, no multiverso de movimentos de intercâmbio, nos quais as mercadorias se medem e se trocam, pondo a cada novo ato de reiteraçáo a vigência do valor como sua determinação mais essencial, na superação da aparência de exterioridade entre dinheiro e mercadoria, entre, na imediatidade da troca, unidade pura de valor e produto do trabalho humano. É na exata medida em que desvela as determinaçóes da relação de valor das mercadorias que a analítica marxiana pode trazer à luz a natureza do dinheiro como forma do valor. Num primeiro momento, como análise da relação de valor das mercadorias, onde o valor se afirma enquanto qualidade ou determinação própria das mercadorias:

As mercadorias, uma vara de algodáo e uma medida de óleo, por exemplo, consideradas como algodáo e óleo, são diferentes por natureza, possuem propriedades diferentes, se medem por unidades de medida diferentes; elas são incomensuráveis. Como valores, todas as mercadorias são iguais 
qualitativamente e diferentes somente em quantidade, todas servem, portanto, de medida umas às outras e se substituem (se trocam, são convertíveis entre si) segundo proporções quantitativamente determinadas. O valor é sua relação social, sua qualidade econômica. (MARX, 1983, p.76).

A mercadoria como valor, na troca por outras, é qualitativamente equivalente a todas as outras, a partir de ihre ökonomische Qualität. Qualidade econômica ou determinação social por excelência, a qual vai aparecer em $O$ Capital como objetividade fantasmagórica, o valor se desvela como forma do ser determinativa da forma social de existência mercadoria. As mercadorias são e representam o valor num material diferente (verschiednen Material), suas propriedades naturais (naturlichen Eingnschaften), qualidades específicas são apagadas. As próprias mercadorias, por suas determinaçóes formas internas, têm uma "dupla existência", onde "[...] ao lado da sua natural uma puramente econômica, na qual ela é um simples signo, é uma letra para uma relação de produção, um simples signo para seu próprio valor." (MARX, 1983, p. 76). Signo e significante, sem nesse passo supor-se necessariamente alguma homologia real entre interatuação formal das categorias e a linguagem, se desvelam num jogo entre abstratividade e concretude, no qual a primeira exerce necessariamente o papel de predominância, de regência na ordem de determinaçóes de existência, mas sem com isso anular-se a figura concreta de produto:

Como valor, cada mercadoria é igualmente divisível; em seu existir natural não o é. Como valor, ela permanece a mesma, ela percorre também variadas metamorfoses e formas de existência; na realidade, se trocam mercadorias apenas porque elas sáo desiguais e correspondem a diferentes sistemas de necessidades. Como valor, a mercadoria é universal, como mercadoria real, ela é particularidade. (MARX, 1983, p. 76).

De um lado, universalidade de valor, pela qual se atesta a relação social na qual e pela qual obtém sua forma objetiva como mercadoria, como valor encerrado numa figura particular continuamente transmutada em signo de sua onipresença prática. De outro lado, particularidade de valor de uso, contentor efetivo da forma social, um ente particular em sua objetividade de coisa, ao modo diretamente material ou qualquer outro que sirva à satisfação do multiverso de carecimentos humanos. Posição de uma contraposição mediada ou de uma mediação contraditória, na qual figura objetiva e existência abstrata se determinam e exigem, enquanto negação do viger exclusivo de cada caráter isoladamente considerado:

Como valor, é ela própria que determina a medida de sua trocabilidade; o valor de troca exprime precisamente a relação na qual ela substitui outras 
mercadorias; na troca efetiva, ela é trocável apenas em quantidades que dependem de suas propriedades naturais e correspondam às necessidades dos cambistas. (MARX, 1983, p.76-77).

Duplicidade de existir que assinala a unicidade de elementos contraditórios, que ganhará posteriormente densidade de determinaçóes na analítica da mercadoria, quando esta terá seu corpo concreto delimitado como portadora do valor.

É no interior dessa prospecção da determinação essencial da forma elementar da riqueza no mundo do capital que o dinheiro vai aparecer. Não mais como categoria isoladamente fixada, abstratamente posta frente às mercadorias, como este se dá na intuição imediata das trocas. Todavia, emergirá do próprio movimento das mercadorias, a partir da relação de valor. Duas mercadorias de tipos diferentes, quando trocadas, afirmam nessa relaçáo, a partir das proporções em que estas se intercambiam que, para além de sua forma "natural", objetiva, particular, que são antes de tudo valores. São cada uma delas portadoras do "mesmo" valor, elas são iguais, como valor realizado, somente na contingência de o ser num material diverso. Nesse sentido, a relação de valor, na qual as diversas mercadorias se inserem, instaura um momento de identificação efetiva das mesmas com base na qualidade social destas, de seu existir como valores. Movimento de troca, o qual, partindo da variegada existência dos valores, na forma de valor de uso, portanto, da irredutível diferença concreta das mercadorias, as põe como figuras de uma identidade absoluta, na qual se apagam mesmo todas as qualidades específicas que as fazem serem objetos de uso diversos. Nesse jogo de identidade e diferença, a qual caracteriza a relação de valor, surge como forma necessária a objetivação do terceiro elemento, do dies Dritte, o valor, como coisa, igualmente concreta frente às mercadorias individuais. Tal emergência somente se dá na medida em que cada uma das mercadorias, como efetivação social de trabalho, ou sendo trabalho humano em geral realizado, já é por si mesma, objetivamente, um equivalente para as demais. Por conseguinte, conclui Marx (1983, p. 76):

Como valor, a mercadoria é um equivalente para todas as outras mercadorias, numa proporção determinada. Como valor, a mercadoria é equivalente; como equivalente, todas as suas propriedades naturais são nela apagadas; ela não está mais, com as outras mercadorias, numa relação qualitativa; ao contrário, ela é tanto a medida universal, quanto representante universal \{allgemeine Repräsentant\}, como o meio de troca universal de todas as outras mercadorias. Como valor ela é dinheiro. 
O dinheiro se determina então como mercadoria, que existe como todas as demais, mas que, ao mesmo tempo, contrastando-se delas, não toma mais a mesma forma de ser; tendo negado seu caráter particular, de ente de valor específico, afirma-se como a universalidade das mercadorias objetivamente expressa. Representante universal, imagem concreta do valor pondo-se frente aos valores, o dinheiro é essa mercadoria, cuja especificidade radica, contraditoriamente, na negação de toda relação ou determinidade específica. $\mathrm{O}$ ser da mercadoria, segundo sua forma de ser determinada, encontra efetividade no dinheiro, realiza-se como universalidade tornada ente e passa a medir e mediar o intercâmbio de valores. A mercadoria se alça assim a ser do valor, sendo valor em plenitude, não mais constrangido pela figura delimitada e finita do valor de uso. Pode, dessa maneira, uma vez liberado da adstrição de ser entidade concreta particular, ser universalidade objetivamente posta, reificada, ao lado das demais coisas. Como terceiro elemento em comum, temse Gemeinsames, agora tornado ele mesmo coisa no mundo, ser medida efetiva, não mais virtual e interna, das mercadorias. As mercadorias, na vigência do dinheiro, encontram enfim sua alma espelhada concretamente numa outra figura mercantil, cuja particularidade ou "forma natural" própria é a de ser forma de valor pura. Somente por essa razão pode o dinheiro servir de medida.

Desse modo, dinheiro é o meio através do qual se realiza a abstração objetiva do valor, como mediação efetiva (wirkliche Vermittung) do processo de transformação da mercadoria, numa figura particular real, em simples signo de valor. Metamorfose real que, para além, e no aquém, da abstração como pura forma do pensar, se coloca como abstração efetiva. Metamorfose da relação de valor em dinheiro e posição objetiva da representação de uma relação social como coisa social concretamente existente frente às mercadorias. Nessa forma de mediação concreta do valor, na equiparação mercantil, ao vir a aparecer o valor numa figura material, se efetiva a necessidade posta pela própria troca de equivalentes:

Como as mercadorias diferem, como valores, umas das outras tão somente quantitativamente, qualitativamente cada mercadoria deve necessariamente diferir de seu próprio valor. É necessário, portanto, que seu valor possua também uma existência diferençável dela qualitativamente e, na troca efetiva, esta distinguibilidade \{Verschiedenheit\} deve tornar-se separaçáo efetiva, porque a diferença natural das mercadorias deve necessariamente entrar em contradição com sua equivalência econômica e que uma e outra possam existir lado a lado apenas porque a mercadoria adquire uma dupla existência, ao lado da sua natural uma puramente econômica, na qual ela é 
um simples signo, é uma letra para uma relação de produção, um simples signo para seu próprio valor. (MARX, 1983, p. 76).

A potencialidade do valor torna-se efetividade posta no dinheiro como caráter objetivo de uma coisa. Uma relação, proporcionalmente efetuada, entre valores, entre coisas de valor ou do valor, se completa como posição do próprio valor como coisa. Nesse contexto, o valor da mercadoria se torna como dinheiro, uma existência particular ao lado dela. Dasein particular-universal, a partir do qual se dá a comparação, a equiparação, a medição das mercadorias individuais umas às outras, forma de ser na qual se resolvem, negando, por conseguinte, sua particularidade natural, a imanência das suas propriedades em benefício da afirmação mediada do seu ser imanente, seu valor.

É a posição da abstração como coisa objetiva que se dá, na sociabilidade do capital, das suas dimensóes mais prosaicas e imediatas àquelas mais essenciais e determinantes, num duplo processo de negação da especificidade. O pôr do valor como figura concreta, complexo de determinaçóes devindo ente se dá, segundo Marx, de um modo dúplice:

A cada instante, nos cálculos, na contabilidade etc., transformamos as mercadorias em signos de valor, nos as fixamos como simples valores de troca, abstraindo de sua matéria e de todas as propriedades naturais. No papel, na nossa cabeça, essa metamorfose se efetua por simples abstração; mas, nas trocas efetivas, uma mediação efetiva é necessária, um meio que opere essa abstração. Nas propriedades naturais, a mercadoria nem é constantemente trocável, nem trocável por qualquer outra mercadoria; ela não o é na sua igualdade natural consigo mesma; ao contrário, ela o é uma vez posta desigual a si mesma como qualquer coisa de não igual a si, como valor de troca. É-nos necessário começar por convertê-la em si mesma em valor de troca para comparar em seguida este valor de troca e trocálo por outros. (MARX, 1983, p.77).

Ou seja, a abstração ocorre em dois modos. Tanto como representação mental, na cabeça (im Kopfe), quando da determinação ideal de seu valor, quanto na objetividade realizada por um signo ou símbolo, uma representação do valor, do tempo de trabalho social como tal. Essa duplicidade, por um lado, afirma o estatuto próprio da analítica marxiana, asseverando a realidade do processo de abstração, para além da sua natureza teórica, é uma componente efetiva da vida social do capital e náo apenas uma figura epistêmica ou gnosiológica. E, por outro lado, em consonância com isso, a abstratividade é determinada 
como efetividade do processo de ser da mercadoria, superando a posição demasiado estreita que coloca a própria troca na dependência da volição dos "agentes econômicos", operação que, evidentemente, exige um interveniente de natureza subjetiva, na medida em que a troca ocorre pela interatividade dos indivíduos sociais:

As mercadorias se transformam em barras, primeiro, na cabeça e na linguagem, antes de serem trocadas uma pela outra. Antes de trocá-las, são avaliadas e, para fazê-lo, é necessário situá-las nas relaçóes numéricas determinadas. Para poder colocá-las em relaçōes numéricas e as tornar comensuráveis, é preciso que elas recebam a mesma denominaçáo (unidade). (MARX, 1983, p. 77).

Isso indica uma relação entre ser e pensar, efetividade e linguagem, na obra marxiana, bem distante daquela afirmada pela compreensão usual do pensamento do autor alemão, que a tem como determinação unívoca e abstrata de uma "base material" sobre formas de puro epifenômeno. Ao revés disso, o que se observa é a presença das figuraçóes ideais como momentos das formaçôes práticas, cujo conteúdo específico se situa no âmbito de sua funcionalidade social. A transformação ideal subjetiva da mercadoria numa unidade de valor não é nem simples elemento fortuito, nem determinativo do valor como tal, mas é momento do processo real de abstração concreta, de posição do valor como objeto da troca.

Não obstante isso, a marcha dos eventos não é posta simplesmente pela subjetividade dos cambistas. É, ao contrário, posição de uma dada forma de ser real da atividade dos indivíduos, a qual determina a forma do produto e de seu intercâmbio societário. Logo, tudo isso depende da forma objetiva de ser social dos entes objetos da troca, das mercadorias, das suas determinaçóes objetivas que as configuram enquanto tais, pois, tornando-se um valor de troca,

[...] um produto (ou uma atividade) não é somente metamorfoseado em uma relaçáo quantitativa determinada, em um número proporcional - a saber, em número que exprime seu equivalente, a quantidade de outras mercadorias que lhe é igual, ou naquela proporção em que ele é equivalente a outras mercadorias - mas é necessário que seja ao mesmo tempo metamorfoseado qualitativamente (diferindo qualitativamente): 1) porque ela não é tempo de trabalho como tempo de trabalho, mas tempo de trabalho materializado; tempo de trabalho não sob a forma do movimento, mas do repouso, não sob a forma de processo, mas de resultado; 2) porque ela não é objetivação do tempo de trabalho em geral que existe somente na representaçáo (que é ele mesmo apenas trabalho separado de sua qualidade, do trabalho no qual a única diferença é quantitativa), mas o resultado 
determinado de um trabalho determinado, naturalmente determinado, diferente qualitativamente de outros trabalhos. (MARX, 1983, p.78).

Proporcionalidade, metamorfose, equivalência são todos momentos objetivos de um processo igualmente objetivo, que convoca a atividade própria da subjetividade, tomada em seu lado ideal, à operaçáo de abstrair, no sentido de realizar o mais plenamente possível a destinação das mercadorias, o que póe a concepção marxiana a uma distância considerável das posiçóes ainda predominantes acerca da temática do simbólico, cujo caráter é seu idealismo mitificado ou mascarado. O simbólico não é expressão de uma pretensa onipotência individual na posição de mundos, mas a posição das coisas do mundo social, tais como são e porque o são, na forma de um terceiro, no qual se afirma a sua natureza societária, posição de uma assemelhação entre "coisas" que, nesse caso particular, póe a figura material que serve como dinheiro como símbolo do valor existente como determinação social de outra figuração objetiva da riqueza. O intercâmbio social e a produção de valor tomam assento como momentos de uma totalidade relacional que inclui, evidentemente, porém, náo somente, o engendramento convencional de um signo tomado como válido. Portanto, "[u]m tal símbolo supõe a aceitação universal \{allgemeine Anerkenung\}; ele só pode ser um símbolo social; ele apenas expressa de fato \{in der Tat\} relações sociais”, expressão que não é apanágio tão somente das disposiçóes subjetivas, mas antes de tudo das relaçóes sociais, das formas de ser concretas nas quais os indivíduos reais interagem. Não é um processo simplesmente instaurado ao nível da subjetividade, nem mesmo da intersubjetividade considerada como esfera normativa, mas é, antes, categorialmente, um processo de conexão social levado a efeito no curso do intercâmbio proporcional de quanta de tempo de trabalho. Dessa maneira, o simbólico tem seu estatuto de ser definido como expressividade das formas de existir da objetividade de atividade e de produto, aqui da mercadoria, e, assim,

[...] representa a parte alíquota do tempo de trabalho; o valor de troca em tais partes alíquotas, como sendo capaz de expressar por meio de simples combinação aritmética todas as relaçóes dos valores de troca entre si. Esse símbolo, o signo material do valor de troca é um produto das próprias trocas, não a execução de uma ideia a priori. (MARX, 1983, p.79).

Por conseguinte, o dinheiro é uma mediação de si a si da mercadoria enquanto valor de troca. O valor de mercadoria assume (erhält) uma existência material separada (eine materiell von ihr getrennte Existenz) da própria mercadoria, forma de ser que se perfaz como unidade de quatro propriedades ou funçóes sociais, as quais são desdobramentos das determinaçóes contidas na própria 
relação de valor entre as mercadorias, sendo o dinheiro mesmo seu modo de expressão objetivo. Em primeiro lugar, como medida da troca das mercadorias, é a efetividade da determinação central das mesmas, existindo como substância ou unidade comum a todas, variando apenas o seu quantum em cada uma delas, o quanto nas diversas mercadorias contém de partes alíquotas de tempo de trabalho. Em segundo lugar, como mediação da própria troca, é o dinheiro o nexo que une e reduz a diversidade de manifestaçóes do valor, tornando possível a efetuaçáo da abstração, pondo em comunicaçáo o valor aprisionado em cada forma concreta e útil dos valores de uso. Nesse sentido, em virtude dos dois aspectos acima referidos, o dinheiro é também a expressão da forma social dos produtos (gessellschaftliche Form der Produkte), do valor de troca, na sociedade do capital, é ele mesmo objetivado (vergegenständlichen) e separado das próprias mercadorias. Exprimindo como coisa, ao modo do repouso, o caráter dinâmico social específico dos produtos do trabalho e da atividade produtiva no mundo do capital, o dinheiro póe concretamente a troca e a torna exequível. Em terceiro lugar, emerge a determinação do dinheiro como representante das mercadorias (Repräsentant der Waren), enquanto imagem ou ocupando o lugar destas, servindo como presença derivada ou em segundo plano do produto do trabalho assalariado, o que o faz adequado a desempenhar o papel de objeto dos contratos. Em quarto e último lugar, Marx destaca a determinação mais central, qual seja, a de mercadoria universal (allgemeine Ware), existindo ao lado de todas as outras. Tal propriedade objetiva do dinheiro faz dele, por assim dizer, a mercadoria perfeita, ou par excellence, na medida em que é o valor existindo em separado do ente que determina na forma de outro objeto, que se oferece igualmente à intuição e à representação dos indivíduos. Mercadoria universal que se póe no horizonte das trocas como aquela dotada de possibilidade infinita de câmbio, metamorfoseandose, assume a forma de todos os valores e, mais importante, faz com que estes revelem sua verdadeira natureza social de trabalho humano sans phrase. Não por outro motivo, o dinheiro será para a relação de produção do capital a forma de realização do valor:

Essa propriedade do dinheiro como mercadoria universal frente a todas as outras, como encarnaçáo de seu valor de troca, faz dele, ao mesmo tempo, a forma realizada e sempre realizável do capital, a forma de apariçáo (Erscheinungsform) sempre válida do capital, uma propriedade que aparece quando da bulliondrains; o que faz com que o capital historicamente comece a aparecer apenas sob a forma de dinheiro. (MARX, 1983, p.80). 
O aparecimento do dinheiro, com todas essas determinaçóes, e não sob uma delas apenas, corresponde a uma necessidade particular de um modo específico de intercâmbio social. Nas relaçôes de troca, as quais quanto mais se desenvolvem, mais tornam os sujeitos dela dependentes, essa forma parece (scheint) ser independente deles. Tem a aparência de uma relação estranha (fremden Verhältnis) aos indivíduos sociais, o que constitui o fenômeno do fetichismo, cujo embrião da analítica a ser executada por Marx em $O$ Capital já se encontra aqui em gestação.

Por via dessa analítica, o dinheiro se encontra despido e desvelado como expressão do caráter social da produção humana efetuada sob o mando do capital. A análise marxiana, ao revelar a determinaçâo precisa do dinheiro, além de expor sua conexão com a forma da produção e da circulação das mercadorias, se afasta da mera admoestaçáo moral contra o valor de troca objetivado e sua abstração dos valores. Muito ao contrário, marxianamente, se acentua o fato de a produção ser, em todos os seus momentos e mediaçôes, algo eminentemente social, mesmo quando tal caráter se torna, não apenas objetivado, mas objetivado em confronto com os próprios produtores, um modo de interdependência societário que corresponde a um dado momento do desenvolvimento do caráter social da produção (gessellschaftlichen Charakter der Produktion). Esse modo objetiva a virtualidade social inscrita na forma de ser da mercadoria. Efetiva-se a superação da diversidade "natural" pelo traço comum advindo de ser posição concreta de trabalho humano social indiferenciado, intercambiável ad infinitum, e colocar em comunicação como ramos de uma mesma produção social tipos de atividade antes existentes isoladamente ou só se influenciando de maneira contingente. Por essa razão, a troca é a mediação necessária da produção e a objetivação do valor a da troca, e o dinheiro se mostra como a encarnação inevitável da sociabilidade da mercadoria, da forma elementar da produção burguesa. $\mathrm{O}$ valor é o cimento ou a argamassa da sociabilidade e o dinheiro sua forma concreta de existir. Assim, não é o dinheiro que produz as contradiçôes e oposiçóes (Widersprüche und Gegensätze) verificadas no curso das relaçōes societárias; ao contrário, é o desenvolvimento dessas contradiçôes e oposições inerentes aos liames sociais do capital que produz o poder aparentemente transcendental do dinheiro (die scheinbar tranzendentale Macht des Geldes). O nexo entre mercadoria e dinheiro, entre o produto do trabalho e a mediação das trocas, supera a aparência de exterioridade e contingência, a que uma mera aproximação histórica poderia engendrar, para revelar-se categorialmente como desdobramento formal objetivo de determinaçóes do primeiro no segundo elemento: 
O produto torna-se mercadoria; a mercadoria torna-se valor de troca; o valor de troca da mercadoria é sua qualidade de dinheiro \{Geldeingenschaft\} imanente; esta sua qualidade de dinheiro se separa dela como dinheiro livre, ganha uma existência social universal, distinta de todas as mercadorias particulares e de seu modo de existência natural; a relação do produto a si mesmo como valor de troca torna-se sua relação com um dinheiro existente ao lado dele ou ainda a relaçáo de todos os produtos ao dinheiro existindo fora de todos eles. Como a troca efetiva dos produtos engendra seu valor de troca, seu valor de troca engendra o dinheiro. (MARX, 1983, p.81).

A partir da dupla existência da mercadoria, na medida em que o valor de troca se despoja de qualquer liame com as características concretas da mercadoria, tal distinção de determinações (uso e valor), dessas duas formas de existir, progride até a diferença (Unterschied) e daí para a oposição e a contradição.

No bojo desse complexo problemático, pode ser destacada a questão da natureza da representação, na analítica marxiana. O problema do estatuto da representação se refere aqui especificamente à transformação, metamorfose, ideal das mercadorias em dinheiro, processo este que não transcorre apenas com o concurso da subjetividade humana e suas formas de ideação, mas se desenrola na efetividade do movimento das mercadorias, obedecendo às determinaçôes da relação de valor. Todo o centro da temática se refere à abstração da forma concreta de sua existência "natural”, própria, em benefício de sua circulação como mercadoria, como valor de troca, como preço. Tal metamorfose, num dado patamar isoladamente tomado, é apenas subjetiva, isto é "nur im Kopf der einziehnen", todavia, toma a forma da representação ideal social objetiva. Ou seja, "in der Vorstellung der Gessellschaft", na representação da sociedade, daqueles sujeitos entre os quais transcorre a relação de troca, sendo uma transformaçáo esta de estatuto diverso daquela efetivada realmente no ato de troca de mercadoria por dinheiro. Nessa perspectiva, o dinheiro não é nem uma criação subjetiva nem uma estrutura, mas expressão objetiva de nexos sociais, por meio da alteração formal da objetivação humana em mercadoria, em valor objetivamente posto. Tal reelaboração de forma se constitui, como nota Marx, um dos dois pressupostos da própria circulação e, portanto, da realização do valor:

[...] para que haja circulação, duas coisas antes de tudo são necessárias; em primeiro lugar, o pressuposto que as mercadorias sejam preços; em segundo lugar, não sejam atos de troca singulares, mas um conjunto, uma totalidade de trocas em contínuo movimento e se operando mais ou menos sobre toda a superfície da sociedade; um sistema de atos de troca. (MARX, 1983, p.119). 
A mercadoria entáo se determina, não mais como ente particular, dotado de propriedades específicas, mas como valor de troca, assumindo a forma da relação social na qual se insere. Diversamente de coisa oriunda da atividade produtiva, a mercadoria se transmuta ela mesma em relação, valor de troca, de acordo com o tempo de trabalho proporcionalmente contido nela, assume-se, ato contínuo, como equivalente de todas as demais. Isso não se realiza sem contradiçóes, na medida em que esse novo aspecto imediato não corresponde ao conjunto de aspectos reais do produto, nem resume a totalidade de suas determinaçóes. O ser, por assim dizer, "natural" da mercadoria não pode simplesmente aniquilar-se em valor, pois negaria a própria troca e com ela a circulação, como série múltipla e multilateral de intercâmbios. Persiste, desse modo, a diferença tensional, contraditória, no seio da unidade da forma mercadoria. Na posição dessa mudança essencial de forma se vê surgir como necessidade a mediação do dinheiro, como representação externa das relações sociais que constituem a forma de ser mercadoria, uma vez que

[o] valor de troca da mercadoria exprime a globalidade das relações quantitativas nas quais todas as outras mercadorias podem ser por ela trocáveis, determinadas pelas mesmas quantidades desiguais, que podem ser produzidas pelo mesmo tempo de trabalho. O dinheiro existe apenas como valor de troca de todas as mercadorias ao lado e fora das mesmas. (MARX, 1983, p. 119).

Esse movimento de troca exige o recurso de uma representação efetiva para realizar-se na plenitude de suas determinaçóes como circulação de mercadorias, como processo de mediação concreta de realização do valor, representação real que é posição do dinheiro como valor da mercadoria, não somente fora dela (außerhalb) e ao lado ou junto às mesmas (neben), mas enquanto traduzido numa forma ideal objetiva, a qual transmuta os próprios termos da relação de troca, como preço. É um segundo momento de metamorfose que se pôe como desdobramento necessário do processo de realização do valor do qual é determinação. A formação do preço das mercadorias não se perfaz enquanto parte contingente e externa à totalidade de relaçóes de intercâmbio, porém, se constitui num coroamento do mesmo, última etapa na qual o valor se autonomiza das mercadorias que determina. Marx entende tal processo de transformação como de tradução. Nesse processo, as mercadorias "[...] devem ser traduzidas em dinheiro \{müssen ins Geld übersetzt\}, expressas \{ausgedrückt\} nele. O dinheiro torna-se o nome universal \{allgemeine Nenner\} do valor de troca, das mercadorias como valor de troca" (MARX, 1983, p. 119); o preço se entende marxianamente como valor expresso em dinheiro, posto como 
similar ou equiparável ao dinheiro. É o último ato de conversão da mercadoria em valor, posto que se apresente em cena trajando unicamente sua máscara abstrata e ideal, numa pura idealidade, a qual nada mais faz senão expressar sem os adornos do valor de uso os contornos que a definem como ente de valor. Como preço, a mercadoria revela seu espírito abstrato e seu ânimo cortês, uma vez que se deixa à livre circulação sem os constrangimentos de uma forma material e particular. Dessa maneira, "[...] a medida universal dos valores de troca devém agora em medida presente entre todos os valores de troca e o dinheiro com o qual se as póe em igualdade." (MARX, 1983, p.120). Tal argumentação marxiana pode auxiliar na enunciação justa de mais de um dos problemas candentes e espinhosos para a intelecção das formas de ser contemporâneas do capital. Entre estes, situam-se aquele da formação dos preços e a questão da medida.

\section{III}

\section{Da DETERMinaÇÁo do VALOR aO PARA ALÉM do VALOR COMO DETERMINAÇÁO} SOCIAL

Não apenas os nexos entre mercadoria, dinheiro e preço se iluminam, mas o próprio caráter do processo do qual estes são determinaçóes, aquele da circulaçáo, se esclarece ele mesmo como parte integrante do circuito do valor em seus desdobramentos, em direção à sua efetivação como capital. Nesse sentido, não se deve iniciar a analítica a partir da figura do dinheiro, de uma forma de ser, de existir, do valor como capital, mas da sua pressuposição, o processo de produção como tal, o que afasta de um só golpe tanto o formalismo ou o esquematismo das categorias fixadas como figuras epistemicamente constituídas, quanto o positivismo que imbui as aproximaçóes teóricas do dinheiro na sua imediatidade, conforme se apresenta na circulação. Assim, como o dinheiro não é uma entificação abstratamente tomada pelo discurso marxiano, com base em sua autonomia aparente (o que não significa falsa ou ilusória, mas apenas como caráter mais imediato), para revelar-se momento de metamorfose do valor, o mesmo ocorre com a circulação, em sua totalidade. O dinheiro desvelado como desdobramento formal da troca, da interação das mercadorias em torno do valor, tendo seu momento de máxima autonomização sua configuração como preço, aponta para a necessidade de apreender o movimento no qual se enquadra o processo do qual é mediação. Como o dinheiro não cria o valor, é a expressão deste na forma de uma coisa, sendo o preço nada mais que o valor posto na sua determinidade como dinheiro, 
como abstração. O movimento de circulação nada mais é que momento determinado da produção e realização do valor, no qual obtém sua virtude de realizar-se como tal. É um circuito que se perfaz por uma mudança simultânea de forma e de matéria do processo:

$\mathrm{Na}$ produçáo tomada por seu lado material, o instrumento vem a ser utilizado e o material trabalhado; o resultado é o produto - um novo valor de uso criado, diferente de seus pressupostos elementares. No processo de produção, tomado por seu lado material, criou-se um produto. Essa é a primeira e mais essencial mudança material. No mercado, na troca por dinheiro, vem a ser expulso do circuito do capital e cai no consumo, tornase objeto de consumo, seja ele satisfaçáo final de necessidades individuais ou como material para um outro capital. Na troca da mercadoria por dinheiro, coincidem a mudança material e aquela de forma; no dinheiro, o próprio conteúdo participa da determinação econômica formal. A reconversão do dinheiro em mercadoria, no entanto, é aqui, ao mesmo tempo, a reconversão do capital nas condiçôes materiais de produção. (MARX, 1983, p.568).

$\mathrm{O}$ que não se deve é fixar-se um dos momentos, tomando-o separadamente como processo autônomo, perdendo-se de vista o horizonte geral a partir do qual se enquadram as determinaçóes e as partes do circuito inteiro. $\mathrm{O}$ dinheiro não é apenas, ainda que o seja considerando-se separadamente as trocas, mediação da circulação, enquanto intermediário en tre a produção e o consumo. No entanto, é também, e principalmente, mediação entre a produção e a produção (Vermittlung zwischen der Produktion und Produktion), onde o termo e o início se encontram, otimizados pelo movimento inteiro de circulação, como posição das condiçóes de reprodução do capital num patamar mais alto de determinação. Por isso, a circulação aparece como momento pertencente ao movimento de alteraçôes formais e materiais, pelo qual passa o valor, até atingir sua realização como capital pressuposto da produção, alteraçóes estas que náo necessariamente coincidem, diversamente do momento da troca, e subsequentemente do consumo, pois, na circulação, não há a reconversão recíproca do dinheiro em mercadorias e do capital em condiçóes de produção, ou seja, pondo na ordem do dia a própria reprodução do capital. A circulação aparece pela trama de conexóes destrinchada analiticamente como momento determinado de modo interno pela lógica da totalidade orgânica do capital, sem, no entanto, ter um caráter propriamente lógico, como etapa ou encadeamento meramente "deduzido" da produçáo. Como momento preponderante da articulaçáo categorial do circuito de engendramento do mais-valor e da transformação final deste em capital, em termos precisos, a produção não deve 
ser tomada, entretanto, como uma instância universal "mais verdadeira", da qual os demais passos do processo subsumidos categorialmente a esta seriam "seus casos" particulares. Nada mais falso em relação à argumentação marxiana. O nexo que une os momentos determinados da criaçáo da riqueza como valor valorizado/que se valoriza é de tipo efetivo que não se coaduna necessária e univocamente a parâmetros de uma lógica a priori, por mais intrincada ou sofisticada (ou mesmo "realista") que seja. As conexôes que concatenam a circulação à reprodução do valor, o incremento real mediado ativamente pelo processo de produção não suprimem a primeira como efetividade finita, ainda que subsumida a momento de um processo que a ultrapassa. Como tal, a circulação, conquanto participe organicamente da produção como esfera virtual - de acabamento, posição da possibilidade concreta de realização do mais-valor na sua forma pura de aparecer, como um montante incrementado de dinheiro, persevera em seu caráter próprio e, por vezes, conflitante com a produção da riqueza da qual é passagem necessária. Concatenação não significa obrigatoriamente identidade ou forma de exteriorização categorial em termos absolutos, o que remete ao caráter contraditório real das mediaçóes do mais-valor, talhe este que advém não em virtude da fisionomia epistêmica da analítica marxiana do capital, mas da articulação mesma na qual essa forma desenvolvida e universalmente posta à produção social de riqueza é atualmente existente, como objeto finito e historicamente determinado. A contradição entre circulação e reprodução, como se verá, não é apanágio nem de uma atribuição de sentido metodologicamente operada, nem o é pela suposição de uma realidade universal absoluta que, por sua existência como princípio de mundo, "se apresenta" nos movimentos finitos.

Feita a necessária ressalva, é oportuno indicar que, com Marx, na circulação, a reprodução é ela mesma momento negado, uma vez que o tempo desta não é tempo nem de produção de um novo valor, tendo a transmutação das condiçóes objetivo/subjetivas de produção em elementos do processo de valorização, nem tem a reprodução como horizonte. Circulação é, não obstante seu caráter de necessidade para o capital, momento de desvalorização do próprio valor posto na forma mercadoria, desvalorização esta que não significa extinção do valor, mas que

[...] o capital passou da forma de dinheiro àquela de uma mercadoria, de um produto, que tem um determinado preço que deve ser realizado. Como dinheiro, existia como valor. Agora existe como produto e apenas idealmente como preço; mas não como valor enquanto tal. Para valorizarse, isto é, conter e multiplicar valor, ele deveria passar da forma de dinheiro 
àquela dos valores de uso (material - instrumento - trabalho assalariado); mas desta maneira, perderia ele a forma de valor e deveria entrar de novo na circulação, para pôr-se de novo nesta forma universal da riqueza. (MARX, 1983, p.317).

Isso contém já em germe a determinação do capital como processo crivado pelo signo da incongruência de momentos, em passos de um mesmo processo, os quais na imediatidade dele não se identificam, nem mesmo se encontram, não obstante se exijam de maneira irrevogável. Valorização e desvalorização não são elementos ou situações absolutamente excludentes, porém, diversamente, se completam na sua negação recíproca, a qual não é como tal, frise-se, em virtude de um postulado lógico qualquer, mas caráter nascido da tessitura própria que os graves e agudos da produção do capital assumem, na sua configuração harmônica, que não se fecha em uma solução final, entretanto, que se reproduz e se reatualiza pelo evolver aberto e inconclusivo de seus momentos concretos. Assim,

[...] a desvalorizaçáo constitui em todos os casos um momento do processo de valorização; seria já simplesmente neste particular porque o produto do processo em sua forma imediata náo é valor, mas primeiro deve entrar na circulação para vir a ser realizado como tal. Quando, portanto, pelo processo de produção o capital é reproduzido como valor e novo valor, então é igualmente posto como não-valor $\{$ Nichtwert $\}$, como algo se valorizando, antes de tudo, através da troca. (MARX, 1983, p.317).

Valorização e desvalorização emergem aqui como determinações divergentes e recíprocas do processo de ser do capital, não na forma simplista e imediata de um antagonismo abstrato. Constitui uma contradição que se "resolve" na própria circulação, com o retorno do capital à forma adequada a si, o capital als solches, como dinheiro, a Form des allgemeinen Reichtums.

A relaçáo pela qual se afirma, por um lado, o nexo essencial entre a produção e a circulação e, por outro lado, o caráter da determinação da segunda pela primeira, aponta para a unidade dos dois momentos enquanto partícipes do processo vital do capital, no qual a circulação perde sua aparência de etapa puramente contingente e indiferente, em referência à esfera da produção propriamente dita, para ser posta como via de realização necessária do valor enquanto valor, no rumo da reprodução do capital. Inicialmente, como posição do capital como valor posto nas mercadorias por intermédio da atividade produtiva que cria mais valor. Em seguida, como transformação do valor aprisionado na forma do valor de uso em valor-dinheiro e valor-preço, no intercâmbio mercantil. Para, finalmente, no último estágio, ser posto ao 
modo do valor por si e afirmar-se na compra de novo trabalho e na reprodução das próprias condiçóes de produção, reinaugurando assim seu circuito de existência como capital, como forma de ser, relação social, autorreprodutora, tendo como telos imanente a autovalorização de si mesma. Unidade dinâmica processual, em cada passo de seu existir, de seu sendo, nada mais faz senáo reproduzir ou tender a reproduzir, como meta, de modo potencializado e ampliado o momento inicial de sua posição. O processo vital do capital, que abarca a circulação como seu meio de efetivação da virtualidade do valor, é em essencial a posição continuada e necessária das suas pressuposições centrais, das condiçôes de produção como condições de valorização. Aqui, valorização e produção coincidem, porque, na medida em que não é na circulação que o valor se póe, mas por virtude dela apenas se realiza, por intermédio do quiproquó das mercadorias, a posição do valor só pode se dar no momento da própria produção.

Tal interatividade produtiva é posta no interior de uma particular forma de ser, de uma relação social determinativa, que define e delimita precisamente o caráter e os limites próprios a cada um dos seus elementos. Marx, por isso, não parte da produçáo como produção em geral, mas da produção efetivamente existente, de um dado modo de produzir, onde se articulam as formas ou categorias sociais de uma dada maneira. Algumas dessas formas ou categorias já existiam em momentos anteriores da produção social dos homens, todavia, ganham novas significação e elaboração no interior deste determinado modo de ser da produção, enquanto outras emergem por virtude desse mesmo novo momento da interatividade social. O capital, como modo de ser da produção atual, delimita o produzir como reprodução continuada e ampliada das suas condiçóes de ser, posta como tendência e princípio da produção, o qual cinge o âmbito das relaçóes e fornece o seu selo característico aos termos que nelas se defrontam. Essa reprodução é, na base da posição dos próprios produtos, unidade entre operação da criação das coisas e o pôr dessas mesmas coisas como corpos do valor, as determinando como stofflichen Träger des-Tauschswerts; tal unicidade entre os processos de produção e valorização, contudo, não significa uma identificação absoluta. Trabalho e capital, ou circulação e produção de valores, por exemplo, não se recobrem, mas se relacionam como momentos de um complexo categorial, a produção no modo de produção do capital, onde o segundo termo determina o primeiro. Determina, delimita, adstringe, mas, de maneira alguma, o elimina ou subsume como mera aparência. A produção de valores não é possível senão ao modus da produção dos valores de uso. Uma determinação, por mais central, preponderante e poderosa que seja, somente 
o é como aspecto determinante de uma dada entidade ou de um processo reais. A postulação da existência do valor como substância autônoma, na sua determinidade própria, sem a interferência de uma categoria concreta, uma mediação efetiva e efetivadora, um corpo que a assumisse, seria a admissão de um conceito especulativo. Da mesma forma, a atividade que põe valor não é, nem pode ser outra coisa, que atividade produtiva concreta. Daí a unidade entre valor e valor de uso existir realmente - fato já assinalado mais acima como contradiçáo no cerne da forma mercadoria, atividade na qual, por meio da criação de valores de uso particulares, do desenvolvimento e crescimento da massa de objetos que satisfazem necessidades humano-societárias, dá-se em concomitância a formação do valor. É a elaboração da riqueza humana na forma do valor que devém autônomo e se realiza enquanto manutenção e incremento do valor quando da transmutaçáo da força de trabalho de potência em valor de uso consumível e consumido pela produção. É a relação entre capital e trabalho onde, através da efetividade das suas respectivas persone, o processo de produção/valorização se desenrola em três momentos distintos, mas necessariamente interligados. Os dois primeiros transcorrem imediatamente na seara da produção, como processo finito enquanto tal:

[...] através do processo de valorização o capital, 1.conserva seu valor através da própria troca (a saber, com o trabalho vivo); 2.cresce, cria sobrevalor. Como resultado desta unidade entre processo de produção e de valorização, aparece apenas o produto do processo, isto é, o próprio capital como ele se origina como produto no processo do qual era pressuposiçáo como produto, que é valor, ou o próprio valor aparece como produto desse processo, e, com efeito, um valor mais elevado, porque conservado como mais trabalho objetivado que aquele o qual era originalmente. Esse valor como tal é dinheiro. (MARX, 1983, p. 317).

Ou seja, há, por um lado, a troca, irremediável com o trabalho vivo, o elemento que traduz em efetividade o valor das condiçôes de produção do valor na medida em que as usa, impedindo assim sua mera deterioraçáo físicotemporal. E, por outro lado, como uma compensação ao capital, por transigir em que o valor assuma a forma pouco diáfana e nada abstrata dos valores de uso, há a posição de um valor a mais, de um mais-valor (Mehrwert). Trabalho cria objetos, coisas efetivas, de propriedades efetivas e imanentes, mas as quais são coisas-valor, coisas-dinheiro, elas são produzidas enquanto tais, como dinheiro. Tal duplicidade não é posta por um ato da subjetividade dos agentes, porém, ao revés, é característica das coisas produzidas como mercadoria, como valor, como momentos do capital. Assim, trabalho imediatamente produz, e se produz como, dinheiro. Náo por certo ainda o dinheiro, em sua pureza. 
O que tem por resultado um dinheiro que "ist nicht als solches gesetzt", posto não na forma de puro valor, mas na de uma mercadoria de certo preço, como algo que deve (soll) ser trocada para "solche realisieren". Por tudo isso, "[c]omo mercadoria ele deve 1. ser valor de uso e como tal objeto de carecimento, objeto de consumo; 2. trocar seu equivalente - em dinheiro - para vir a ser trocado. Na venda pode, primeiro, realizar-se seu novo valor" (MARX, 1983, p. 317), o que faz aparecer a circulação na determinação mais acima aludida, como momento do processo de produção/valorização. É o momento de posição do capital como tal, "Kapital als solches gesetzt wird", o retorno do capital à sua forma dinheiro, numa rota inversa àquela da produção. A produção do capital pede a circulação enquanto seu ato de complemento, de efetivação de seu elemento característico, o valor, para pô-lo numa forma própria despida do peso da particularidade concreta dos usos e necessidades humanos particulares. A circulação é, como tal, posta pela produção como exigência de dar ao valor a existência social mais pura possível, demanda à qual a produção não pode, sob o risco de não realizar-se, eximir-se de responder afirmativamente. Desse modo, portanto, o trabalho cria valor de uso para reproduzir o valor, e só pode fazê-lo dessa forma para colocá-lo a circular, para impulsioná-lo ao jogo do ir e vir social no mercado, uma vez que, em não tendo uso, não é trocado, não circula e, ao invés de realizar-se como dinheiro ao final, o valor feneceria.

O capital aparece assim no discurso marxiano, por obra de sua análise categorial, não como uma coisa. A materialidade ou a objetividade própria das condiçóes não são o problema; a questão é de outra ordem. O capital se revela, na analítica, como forma de ser social, como uma dada relação que institui ordens de determinação e de caráter, determinação e característica das coisas, nelas como imanência formal, dação de modos específicos de existir que as fazem tal ou qual. Tal liame social emerge como unidade de momentos de interatividade que se integram, não sem problemas, pela via de seus rumos e veredas, os quais, dado o modo de ser intrinsecamente contraditório do capital, abrem desvãos que se alastram e dilatam ou contraem as vias de fluxo do movimento do capital, na medida em que progridem em sua reprodutibilidade sem termo. Essa valorização só é posta, completamente, na plenitude de suas determinaçóes, pela mediaçáo da desvalorizaçáo. Por isso,

[n] o próprio processo de produçáo-ondeo capital permanece constantemente pressuposto como valor - sua valorização aparecia como inteiramente dependente da única relaçáo entre ele próprio como trabalho objetivado e o trabalho vivo; isto é da relação entre capital e trabalho assalariado. Mas agora 
como produto, como mercadoria, ele aparece dependente da circulação, a qual é exterior a esse processo (MARX, 1983, p. 317).

Não por outra razão, no curso de sua análise, Marx irá surpreender o progresso prodigioso dos meios de produção e circulação, já tão característicos de nossos dias, como tendência irremediavelmente posta no horizonte da sociabilidade do capital. Não como uma sua pretensa tendência benevolente ao progresso humano, mas como modo de atingir a meta de tornar o menor possível o peso da necessária desvalorização de si (MARX, 1983, p.444-447). O resultado da elaboração analítica assim delineada remete diretamente à questão do desenvolvimento das potências humanas de autoproduçáo, das forças produtivas, em sua relação tensional e contraditória com as formas de ser da interatividade social do capital, o que faz aparecer também como imperativo científico a natureza real das contradiçóes aí instauradas, as quais em Marx, diferentemente do que ocorre na especulação filosófica em geral, não encontra uma solução epistêmica de cunho lógico, mas depende sempre dos complexos reais em questão. No bojo dessa questão, cujo alcance escapa ao escopo deste artigo, se póe outra, mais que pertinente e decisiva, antes de tudo, de um ponto de vista científico: a da necessária natureza evanescente das formas sociais de ser e dos modos que estas integram; o estatuto categorial da própria existência histórica no pensamento marxiano. Trata-se de um problema que, não obstante seu longo e acidentado percurso na tradição do pensamento marxista, teria de ser recolocado sob novas bases, a partir da discussão precedente.

\section{IV}

O VALOR COMO DETERMINAÇÃo REAL E A EXPOSIÇÃO MARXIANA DO VALOR: MüLLER E REICHELT

Uma vez cumprido o roteiro de acompanhamento analítico da teorização marxiana acerca do valor como determinação de existência na forma mercadoria, cabe aqui uma discussão em torno de seu sentido científico preciso. Esclareça-se, entretanto, o escopo deste momento. Não se trata de uma discussão sobre a superioridade ou debilidade epistêmicas da Crítica da Economia Política em abstrato. Algo como uma disputa de "racionalidades". Entretanto, antes, de examinar o caráter inerente à propositura de Marx, remetido sempre à delimitação categorial de ordem ontológica, como já se insistiu acima. No decurso desta ponderação conclusiva, é importante trazer ao debate duas das multivariadas leituras do estatuto marxiano das categorias que se centraram no valor e em desdobramentos. São elas as de Marcos Müller 
e de Helmut Reichelt. Essa eleição se justifica não apenas pelo esforço íntegro e de fôlego empreendido pelos autores em questão, mas também porque ocupa destacado espaço nas argumentaçóes um problema marxológico central: o das relaçôes - e de quais tipos - que podem ser verificadas entre a analítica do valor exposta como desdobramento categorial e a arquitetônica teórica hegeliana. A "recuperação" de um núcleo racional do pensamento de Hegel, obnubilado e prejudicado, segundo Marx, pelo seu invólucro mistico de caráter logicizante, faria da teoria valor marxiana uma realização científica da integração especulativa de momentos da totalidade social? Assinale-se que evidentemente não é possível negar de modo cabal a presença de reconhecimentos marxianos do desenvolvimento de racionalidade compreensiva objetivamente posta no pensamento hegeliano. O que é de todo diverso de pretender flagrar como arrimo categorial da analítica das Daseinsformen do valor a execução de uma lógica a priori. A dignidade ontológica do finito efetivamente existente, do qual as categorias são determinações de seu ser, e não um ser, não obstante a forma fulgurante do dinheiro realize o valor como coisa ao lado das mercadorias, parece firmar-se como um point d'honneur da cientificidade marxiana. Adverte-se liminarmente que os escritos dos autores a serem discutidos foram selecionados por sua representatividade para o ponto que se esclarece, assim como pelos limites deste trabalho, um de cada que permite avaliar melhor o horizonte da polêmica.

O primeiro desses escritos é já um caso clássico das discussóes a propósito da questão do caráter peculiar da exposição categorial da crítica da economia política exercitada em O Capital, no Brasil. Em Exposição e Método Dialético em "O Capital", Müller pretende acercar-se do talhe específico do desenvolvimento conceitual marxiano, aferindo tanto o que o ligaria à especulação hegeliana quanto as pontuaçóes que desta a distanciariam. Esse é um objetivo importante, quando se trate de compreender o estatuto de uma cientificidade que intenta expor o caráter contraditório da articulação das categorias da produção capitalista, sem, entretanto, situá-la nos marcos do enquadramento da lógica hegeliana do absoluto. No entanto, o autor brasileiro acaba por unilateralizar a relação de Marx com Hegel, porquanto acentue de certa maneira muito mais a continuidade que o afastamento, ao afirmar, por exemplo: "O conceito de 'método de exposição' em Marx guardará não só reminiscências do conceito hegeliano de exposição, mas um dos seus elementos essenciais." (MÜLLER, 1982, p. 20). Nesse sentido, não obstante declare considerar a distinção da forma de entendimento do conceito em $O$ Capital frente àquele da lógica, quando trata de abordar essa questáo, o 
peso específico da herança hegeliana no pensamento marxiano tende a ser um centro da composição discursiva de Marx, em detrimento da construção de uma cientificidade particular de talhe analítico.

Esse aspecto da leitura de Müller se torna em especial patente, no tocante à forma como Marx descreve a sua concepção do desdobramento conceitual da apreensão do real e sua expressão discursiva. Com relação à célebre passagem de $O$ Capital, na qual define a dimensão da idealidade nichts andres als dasim Menschenkopf umgesetzte und übersetzte Materielle, Müller rebaixa o conceito de espelhamento conceitual à noçáo ambígua e reduz a teoria marxiana das abstraçóes razoáveis ao nível de uma mera metáfora (MÜLLER, 1982, p. 36), a qual, segundo ele, uma vez mal-entendida em seus limites, foi assimilada nas teses da vulgata marxista em torno de uma apreensão direta e transparente da objetividade pelo entendimento. Evidentemente, inclusive pelo exposto nas seçōes anteriores deste artigo, nada tem menos a ver com Marx que a afirmação de uma conaturalidade entre objetividade e subjetividade, menos ainda a asserção de uma apropriação imediata do concreto pela consciência como base do conhecimento. Porém, o fato de o pensamento marxiano ser tributário também da crítica da metafísica em geral, não significa que este se filie às "soluções" transcendentais ou considere a resolução metodológica a priori como a armaçáo primária sobre a qual se erga o edifício contingente e em permanente construção da teoria. Diversamente, do indicativo da determinação social do pensamento, em geral, e da cognição, em particular, abre-se uma via crítica para a compreensão da atividade do conhecimento em suas condiçóes efetivas, históricas concretas. É, certamente, uma delimitação ambivalente, que não atina apenas com os limites dados pelo horizonte, mas igualmente para o terreno de possibilidades a cada momento existentes, condicionados ambos pela concretude finita e determinada da vida social. Assim, o Widerspiegelung não é um conceito arrimado na descrição antropológica de uma subjetividade universalmente dada. Antes, a natureza das possibilidades de construção de sujeitos concretos que conhecem decorre do modo como a experiência humana de estar no mundo se determina pelas condiçóes sociais objetivas desse Dasein e de qual feitio das formas de individuação e de racionalidade possíveis encontram existência real. Portanto, a universalidade da transposiçẫo e da tradução, em não sendo ancoradas em uma "concepção de natureza humana" ou coisa que o valha, não se afirma como generalidade determinante, mas tão somente em seu caráter de modo único que o conjunto de condiçôes reais da consciência, $\operatorname{der} K o p f$, que não é nem transcendental, nem biologicamente dada, tem de realizar seu confronto com o que precisa ser conhecido. Afora isso, o detalhamento de Marx, no Posfácio a $2 a$. 
edição de O Capital acerca da ordem da produçâoo do concreto pensado, retoma em essência as observaçóes contidas na Introdução de 1857 aos Grundrisse.

Por esses motivos, revela-se inadequado ponderar a passagem marxiana em questão como uma simples "metáfora". O que está em jogo é, antes, a natureza da apreensão ideal, que é sempre primeiramente de natureza analítica, das conexôes categoriais reais. No espelhamento marxiano, não se trata de um reflexo ou impressão cerebral passiva, mas de um ato de conhecimento que é analiticamente procedido para, uma vez identificados os nexos determinativos, poder-se posteriormente expor a síntese categorial que reproduza o efetivo em sua inteireza e prioridade, independentemente dos volteios metodológicos mais ou menos sofisticados do pesquisador. Aqui, o prezado Prof. Müller parece não atinar para todo o potencial elucidativo do espelhamento: ele o aproxima de um decalque neuronal, quando se trata de expor a síntese real como síntese pensada, na qual a ordem das determinações e as simetrias observadas podem ser exatamente o inverso daquilo que a intuição sensível ou prática imediata possibilita capturar. Uma vez que não reconhece a determinação social do sujeito concreto e ativo que conhece, talvez, senão como versão de uma sociologia do conhecimento, o importante estudioso de Hegel precisa encontrar uma dupla ancoragem; de um lado, a especulação hegeliana e, de outro, uma concepção tributária da semântica do termo: "N'O Capital ele só pode ser entendido adequadamente a partir de sua origem na dialética especulativa hegeliana, e da sua dependência da concepção tradicional de teoria no seu sentido etimológico de visão." (MÜLLER, 1982, p. 36). Com relação ao segundo aspecto, não se trata de "visão", mas do como os objetos aparecem no espelho. Ao inverso daquilo que são - uma síntese dada no concreto -, surgem ao final do processo de cogniçáo teórica como produto desse mesmo caminho conceitual. O termo espelhar precisa ser levado a sério, como expressão inversa daquilo que expressa: o real concretamente existente, o finito atualmente existente é uma síntese efetiva, natural ou social, "dada" aí; já a sua reconstrução espelhada conceitualmente é a síntese de determinaçôes resultado final de um movimento que se inicia de modo analítico e termina como síntese pensada de determinaçôes, mas a própria síntese precisa obedecer à differentia specifica identificada pelo processo de conhecimento.

Esse aspecto do tema tem como correlato obrigatório aquele do estatuto de ser do próprio objeto e da sua consistência categorial, a sua concretude como coisa. Afinal, o que significa concreto, em Marx? Em que sentido essa 
determinação se distingue da sua definição em Hegel? A esse respeito, Müller (1982, p. 22-23) observa que

[...] o verdadeiro (Hegel), o racional e o concreto (Hegel, Marx), não são de acesso imediato a qualquer tipo de intuiçấo intelectual ou experiência direta, [...] eles são resultado de um movimento de pensamento, do que Hegel chama de "trabalho do conceito", que expóe progressivamente [...].

Todavia, para Marx, o Konkretum se diz sempre de dois modos. Primeiramente, como concreto efetivamente existente, síntese real e imanente de categorias, e, em segundo lugar, como concreto pensado, reproduzido teoricamente por um movimento de tradução analítica e transposição para o registro ideal que deve cuidar de expressá-lo o mais fielmente possível. Nesse contexto, embora retome de Hegel a precisão da concretude como uma unidade sintética de múltiplas determinaçôes, o que aparece à intuição e à representação como dado imediato é em realidade uma síntese posta ou dada, naturalmente ou pelas vias da interatividade social objetiva dos homens, de categorias que perfazem a coisa, o que é, numa determinada figuração morfológica dinamicamente existente segundo a preponderância formal de algumas daquelas. É o registro primário da concretude que delimita como parâmetro da particularidade efetiva das categorias a reprodução cognitiva destas no ato de conhecimento.

Assim, no pensamento de Marx, o empírico, segundo sua acepção de existente, possui uma dignidade ontológica, uma precedência como existência atual de complexo categorial que supera o modo como o empirismo, tanto em sua versão clássica quanto pragmática, normalmente o consideram. É algo que o estudioso brasileiro apreende ainda apenas pelo viés hegeliano, o qual, evidentemente, não reconhece a espessura de ser por-si como caráter do empírico, como pode ser observado na passagem a seguir:

[...] o verdadeiro concreto da realidade capitalista não é dado pela experiência direta da circulaçáo de mercadorias e pelo movimento dos preços, isto é, pelas categorias da circulação, mas é o resultado de um processo de pensamento que reconstrói a constituição sistemática do capital a partir das determinaçóes mais simples, abstratas e aparentes da produção capitalista (mercadoria, valor, dinheiro, circulação), para chegar às mais ricas, concretas e essenciais, através da explicitação das categorias da produçáo a partir da lei da valorização (mais-valia, exploraçáo, tempo de trabalho, trabalho necessário e excedente, mais-valia absoluta e relativa, cooperação, divisa:o do trabalho, maquinaria, trabalho assalariado, reproduçáo e acumulaçáo, para indicar algumas das principais categorias do Livro I d'O Capital). (MÜLLER, 1982, p. 23). 
No entanto, isso somente vale no que respeita ao conhecimento do concreto, mas não da sua existência como tal. Marx parte exatamente do reconhecimento do efetivo por-si, como forma real e autossuficiente de ser, e não somente em-si, como forma vazia dada à cognição. O ser do que é efetivamente o é como plenitude categorial objetiva (CHASIN apud VAISMAN, 2011, p. XX). Não é, pois, resultado do pensamento, este último "somente" o espelha em correspondência maior ou menor de acordo com sua eficácia, a qual depende objetivamente de uma série grande de condiçóes reais que simultaneamente se situam aquém e além da esfera da atividade cognitiva tomada em separado. A verdade do concreto não é dada imediatamente à percepção dos agentes econômicos, não obstante, de outra parte, aquela não é produto da exercitação de uma chave-mestra racional - seja esta de talhe metodológico-transcedental, seja no contexto da identidade mediada entre as lógicas do ser e do conhecer -, e sim de uma atividade concretamente determinada de sujeitos sociais reais em confronto com a objetividade de relaçóes categoriais que delimitam o existente. Assim, o "verdadeiro concreto" também se diz de dois modos: o concreto como a coisa efetiva, que, apreendida somente no nível da intuição e da representação, não se mostra em sua natureza de síntese de categorias. E, também, em dependência com o reconhecimento ontológico da positividade do real e de seu ser, o concreto pode existir igualmente como concreto pensado, reproduzido pelo e no pensamento como uma síntese de categorias reconstruída pela atividade cognitiva.

Fiando-se numa proximidade de Marx a Hegel, suposta como filiação teórica, Müller assevera: "O verdadeiro concreto, que era, para Marx, o resultado de sua reconstrução sintética no pensamento, tende a ser confundido com uma imediatidade factual, com o 'concreto empírico e imediato' de Marx [...].” (MÜLLER, 1982, p. 37). O verdadeiro concreto pensado, a concretude da população não é negada, uma vez que ela permanece, segundo Marx (Cf. 1983, p. 40), como pressuposto sempre a servir de métrica para conferir o lugar determinado das abstraçốes umas frente às outras, na reprodução ideal do concreto efetivo. O verdadeiro concreto é o concreto da efetividade socialmente existente fora do pensamento. Ele é uma síntese real de determinaçóes objetivamente dada. As formas do pensamento e aquelas do real não possuem congruência e menos, ainda, identidade, para Marx, porquanto a realidade social continue existindo com sua "lógica" de ser "fora do cérebro" que a perscruta. Aqui, Müller parece reduzir o empírico, como existência, à empiricidade imediata, quer dizer, tem-se o velho artifício idealista de tornar o atualmente existente somente algo atinente à sensibilidade imediata. $\mathrm{O}$ 
fato de a forma de existir dos objetos por-si independente dos sujeitos e da relação que estes tenham com eles determina a apreensão aproximativa do conhecimento por suas camadas, das mais imediatas da prática àquela da apreensão propriamente científica. $\mathrm{O}$ conhecimento, para ser apropriação das coisas, num sentido efetivo, parte do reconhecimento de que não se produz por um automovimento, mas por um caminho cuja intencionalidade é a alteridade objetiva.

À contextura altamente complexa das relações entre dimensões, internas e externas à cognição, pressupostas ao discurso de Marx, Müller intenta enfrentar da seguinte maneira o desafio de apreender a determinação do modo de exposição:

[...] a sua proveniência especulativa como forma de auto-exposição do conteúdo: a dialética é um "modo de apropriação do concreto pelo pensamento" (C. 22), um 'método de elaboração'(45) que "reproduz” (G. 22) o concreto que as ciências empíricas analisaram e prepararam para a exposição, que então "transpóe", "traduz", ... expressa" idealmente o movimento efetivo do conteúdo e "espelha idealmente a vida do material". (MÜLLER, 1982, p. 30).

Entretanto, nãoéa “dialética”, mas, antes, o procedimentoanalítico queengendra as abstraçóes razoáveis, num primeiro momento, e depois as concatena em correspondência com as relaçôes de determinação particular que as categorias têm no concreto objetivamente finito, atualmente existente. A síntese pensada é um espelhamento da síntese existente dada, independentemente de qualquer operação do pensamento; é resultado da atividade cognitiva que forceja, nos seus dois grandes momentos, da análise e da síntese articulatória, pôr em evidência a totalidade concatenada que faz do efetivo o que ele é. $\mathrm{O}$ modo de apropriação em Marx é por excelência analítico, é o momento preponderante da cognição, na medida em que este permite apreender e compreender tanto as categorias em sua particularidade quanto o remetimento recíproco de umas pelas outras, conforme cada complexo determinativo em questão. Por isso, não há em Marx igualmente a identificação de uma categoria determinadora "em última instância", em sentido absoluto.

Ainda com referência ao problema da relação entre analítica e exposição categoriais, Müller por certo não desconsidera a posiçâo de uma incongruência entre a crítica marxiana e a concepção hegeliana. Sustenta ele haver uma mutação de sentido importante: 
[...] desde que este tenha sido analiticamente investigado e a sua maturação histórica o tenha levado a um ponto de diferenciação e organicidade suficientes para a exposição(46). Dialética transforma-se, assim, em método no sentido subjetivo de um procedimento de reconstrução categorial [...] (MÜLLER, 1982, p. 30).

A questão da distinção se dá na exata medida em que, para Marx, a determinação da differentia specifica não é um mero ponto de passagem no desenvolvimento de uma substância infinita, traço dum existir a ser superado em sua verdade parcial pela verdade da totalidade integradora, mas é, antes, ele mesmo 1 - possuidor de dignidade ontológica, existente efetivamente concreto frente à universalidade, entendida ou bem como um conjunto de traços comuns, ou bem como abstração razoável ou, na melhor das hipóteses, como conjunto de aspectos que se fizeram irreversíveis no curso do processo; 2 - uma totalidade de relaçóes, uma articulação categorial, da qual participam elementos em interação recíproca, cujo acento determinativo depende da função de preponderante ou de determinado que possam cumprir efetivamente em certos complexos objetivos. Por esse motivo, afirma ele:

O método não é mais a forma do automovimento do conteúdo que se expóe, mas um procedimento de reconstrução categorial que pressupóe o trabalho prévio de investigação das ciências empíricas e a maturação histórica do objeto para então expor a sua lógica interna de acordo com os nexos que a análise apreendeu entre suas determinaçôes. (MÜLLER, 1982, p. 30).

Esta é evidentemente, para Marx, a única forma racional não mística de um método. O pulo do gato marxiano é exatamente que esse conjunto de procedimentos depende de maneira determinada do complexo de categorias que os sujeitos reais, vivos e ativos, socialmente constituídos e delimitados, têm de enfrentar cognitivamente para explicar. Marx não pretenderá que a metodologia, ou o desenho do caminhar, possa ser "aplicável" de modo abstrato: vide a comparação que ele faz do processo de conhecimento das formas sociais de existência da produção com aquelas mobilizadas em outros terrenos científicos, por exemplo, Marx (1998, p. 12, 65). O equipamento cognitivo humano na sua aplicação à prática do conhecer está irremediavelmente condicionado pela natureza do objeto a ser conhecido, assim como das questôes específicas por este suscitadas.

Essa posição é diferente, por seu fundamento, seja daquela da tradição nascida com o cogito e desdobrada criticamente por Kant como uma teoria do sujeito a priori, seja da tentativa de solução da conexão aporética de suas substâncias isoladas, sujeito e objeto, identificando-os dentro de um modo 
panteísta, como ocorre no pensamento hegeliano. Entretanto, alargando o escopo declarado textualmente por Marx, o estudioso brasileiro alinha sua leitura dentro dos parâmetros de uma "transformação materialista" da dialética:

Aqui surge a questão crucial do projeto marxiano de transformação materialista da dialética especulativa: como retomar a idéia de conhecimento dialético sem comprometer-se com a componente especulativa da exposição dialética e sem romper com a crítica do jovem Marx aos seus aspectos mistificadores e harmonizantes? (MÜLLER, 1982, p. 24).

Colocá-la de pé ou assentá-la nas próprias coisas e não in Kopf, não é transformar uma dialética especulativa em "materialista", mas encontrar a articulação que as categorias têm na totalidade finita e real, para compreender e expor seus nexos efetivos de determinação. Além disso, assinale-se, essa crítica está no próprio Das Kapital e não apenas naquelas de constituição inicial (1843-1849). O lado positivista, retrógrado e apologético da dialética hegeliana continua sendo denunciado em favor do reconhecimento de um mérito, que, por si mesmo, é muito limitado - o ter enunciado as leis do movimento em geral. Lei do movimento em geral vale apenas como abstração do movimento real, que pode razoavelmente reter alguns padrốes, mas que assim, nesse registro, não respondem por movimento efetivo algum. O caráter dinâmico da realidade é certamente um momento importante das elaboraçóes hegelianas, todavia, se perde quando essa dinamicidade é convertida de determinação em sujeito real. Não obstante reconheça à frente o papel decisivo da captura analítica das determinaçóes, pois uma apresentação categorial justa da coisa “[...] pressupóe a apropriação analítica do objeto prévia à sua exposição em suas articulaçôes necessárias, toma-se para Marx o conceito determinante e central de dialética" (MÜLLER, 1982, p. 31). Há, no entanto, que se questionar: mas e o Reise wieder rückwärts? Esse momento igualmente importante, delineador das categorias em sua particularidade em correspondência à forma do existente, conforme assinalado, em 1857 (MARX, 1983, p. 35), que veda o procedimento de tornar as abstraçóes formas universais puras ou meras tautologias, parece não merecer a atenção de Müller. Marx acabaria caindo numa espécie de aristotelismo, na medida em que o existente serviria táo somente à recolha da identidade categorial ou dos aspectos determinantes comuns, não possuindo o papel de indicador da distinção histórica fundamental das categorias. Conhecer é distinguir, é determinar, não na subsunção total ou na submersão do particular ao universal, porém, identificando o modo específico e próprio de vigência dos aspectos universais numa forma particularizada real. Daí a necessidade de a atividade cognitiva ter sempre diante de si o concreto 
efetivamente existente, por exemplo, a população determinada pela sua existência como totalidade de relaçôes travejadas pelos antagonismos de classe e pelas categorias da produção específicas ao capital. Desse modo, a exposição marxiana, ao apresentar discursivamente a articulação das determinaçóes, o faz preservando a diferença real entre as formas expressivas do valor, de uma parte, e como estas aparecem por meio de um concreto pensado, de outra parte. Não há, ou ao menos não deve haver, congruência imediata, menos ainda identidade, daqueles dois registros, sob pena de recair-se na especulação filosófica. $\mathrm{O}$ fato de a abstração do trabalho, exempi gratia, possuir um caráter objetivo que deve ser apresentado teoricamente náo redunda necessariamente no apagamento da distinção acima mencionada. E isso se dá exatamente porque o caminho da análise é o pressuposto da exposição e não o contrário. O conjunto de determinaçôes articulado não é visível no nível da intuição e da representação, porém, está lá imanente ao concreto, com sua legalidade existente de modo independente da investigação. É a reconstrução do objeto, em sua concretude, que supera seu aspecto imediatamente dado, como síntese de determinaçôes efetiva e por-si. Não é uma apresentação da coisa em sua historicidade cronológica e sim na sua tessitura de objeto que é desvelado na direção do entendimento teórico da rede de determinaçôes que fazem com que aquela seja o que ela é.

Nesse diapasão, O capital não é apenas conceito lógico, integrante de uma teoria, mas é também, e antes, uma categoria, Daseinsform preponderante que determina, não obstante de modo não-visível, o ser da própria forma mercadoria. É descoberto como tal, porque se destrincham os pressupostos sociais efetivos da forma dos produtos do trabalho humano como realização e veículos da valorização do valor dos meios objetivos de produção. A exposição - dialética - das categorias apresenta o seu modo de articulação efetivo, com sua interpenetração característica e suas formas específicas de remetimento recíproco, as quais não se resolvem pelas virtudes de uma lógica, contudo, na medida em que o pensamento consiga expressar como elas são na realidade, o que abre caminho para a discussão do segundo comentador, Reichelt, que pretende explorar as diversas vias do que, segundo ele, constituiria o processo de elaboração lógica do conceito de capital.

Uma primeira observação crítica a Reichelt é que ele, por um lado, tem o mérito de não gretar Marx em "jovem" e "velho" como figuras contrapostas, numa saudável reaçáo à tese althusseriana da coupture. No entanto, por outro lado, o autor alemão acaba por forçar um desenvolvimento simples, 
nos contornos do qual os períodos do pensamento marxiano se sucedem, no tocante às temáticas mais particulares, como um todo que se medraria de maneira unívoca. Evidentemente, a obra de Marx exibe claras linhas de continuidade, em nada se parecendo com uma crise em operação perpétua. Por isso, trata-se de um processo de constituição de um determinado padrão de cientificidade e de reflexão geral, no qual estão conformados os conceitos e figurações teóricas que podem ser alterados, aperfeiçoados, cunhados e até mesmo abandonados. Mas, de outra parte, considerar todo este processo como uma continuidade em oposição a uma descontinuidade sem mais pode não permitir entender certas diferenças importantes, tanto da conformação do que Chasin (2009) denominou estatuto ontológico, quanto dos momentos conceituais particulares e atinentes a cada problemática à qual Marx voltou sua atenção, como cientista e pensador. Essa advertência, diga-se de passagem, pode ser válida, em certa medida, igualmente para Müller, porquanto este parece náo distinguir a amplitude relativa das diferenças advindas do Ausgangspunkt (ponto de partido) entre os Grundrisse e Das Kapital. A analítica das coisas, de um lado, começa pelo capital em geral e, de outro, este aparece no curso da analítica das Daseinsformen como pressuposto determinativo social real, da circulação simples como imediaticidade do intercâmbio e da forma elementar da riqueza como o capital em sua forma imediata de aparecer.

No tocante à elaboração de Reichelt, cabe advertir de saída que não se tomará para exame a totalidade de A Estrutura Lógica do Conceito de Capital em Karl Marx, mas apenas algumas seçóes do capítulo 3, intitulado A Exposição Categorial, as quais possuem uma relaçáo direta com o tema das formas do valor, conforme explorado neste trabalho. Nessa perspectiva, a determinação principal a ser discutida aqui é a centralidade atribuída pelo autor alemão ao estatuto lógico das categorias de $O$ Capital, o que se encontra especialmente evidenciado logo de saída no título mesmo desse subcapítulo, o qual denuncia e prenuncia o talhe de certo modo tradicionalmente epistêmico da aproximação: Sobre a relação entre método lógico e método histórico. A cientificidade marxiana teria como fundamento a exercitação de dois métodos relativamente independentes, os quais ocasionalmente se cruzam como atos de performance puramente gnosiológica, rastro de uma questáo antiga e ambígua das leituras da obra de Marx. A problemática da conexão entre a forma de existência atual das categorias, a descrição crítica da articulação de determinaçóes sociais objetivas de existência de um dado modo de produzir a vida humana é convertido num assunto atinente à arquitetônica teórica. De outra parte, o concreto apenas apareceria em sua tessitura histórica, como 
uma série de eventualidades mais ou menos conectadas pelo decorrer de suas temporalidades. O capital como categoria contaria apenas como figuração ideal ou conceito e não como uma determinação social objetiva do existente atual. Não por outra razão, as avaliaçóes marxianas acerca da Economia Política, que, como ciência frente à empiricidade imediata da produção tomada como forma natural, deveria "desmantelar essa falsa aparência", em especial o ajuizamento acerca de Ricardo, em suas incompletudes e lacunas necessárias que aparecem circunscritas a um terreno puramente epistêmico:

[...] o fato de ainda assim acabar capitulando se deve à circunstância de não ter discernido a natureza das categorias. A isso Marx também atribui que o método da teoria burguesa sempre permanece exterior ao seu objeto, e isso, por sua vez, tange a forma de exposição do processo global. Marx aborda apenas marginalmente esse assunto, mais propriamente apenas quando trata de Ricardo. Ele o elogia, como já expusemos, por causa da rigorosa coerência do seu procedimento, mas, ao mesmo tempo, indica que ele toma as categorias a partir do campo empírico, pressupondo-as como dadas (em vez de primeiro desenvolvê-las), para demonstrar a sua "adequação à lei do valor". (REICHELT, 2013, p. 134).

Ou seja, a objeção marxiana aos limites dos economistas se resumiria ao aspecto diretamente teorético, aqui de caráter lógico, ao modo a priori de estruturar a aproximação para com a efetividade da produção. $\mathrm{O}$ desenvolvimento das categorias encontraria sua caução numa armação lógica de contradições pela virtude da qual o desvelamento da aparência imediata se daria como resultante de operaçôes de um esquema prévio, no qual aquelas encontrariam seu nexo, liame de determinação então antes fruto de uma atribuição, não tanto de uma descoberta. $\mathrm{O}$ que pode evidenciar-se do acompanhamento anteriormente feito das elaboraçóes da crítica é antes algo de todo diverso. "Desenvolver" as categorias só pode ter um sentido de extrair da aparência seus pressupostos, as relações determinadas, nelas ocultos, por exemplo, mais-valor como síntese de mais-trabalho; não se trata de uma dedução de umas pelas outras, como num procedimento axiomático antes é o exercício de uma analítica formal, ou seja, das formas ou de eidos que inerem como determinaçóes, preponderantes ou delimitadas, nas coisas. Além disso, nesse diapasão, a propositura marxiana como tal aparece como mais uma economia política, o que obnubla demasiado a especificidade que a dimensão crítica possui para a cientificidade de Marx. Não! Não é a tarefa possível para economia imediatamente desvencilhar-se daquela aparência. O limite de uma teoria econômica como ciência "normal" resume-se a descrever as formas aparentes como a totalidade do fenômeno, é o máximo a que esta pode aspirar. A tarefa de escavar para além das 
Erscheinungsformen é da Crítica da Economia Política, que não é uma simples nova versão das teorias econômicas.

O remetimento mesmo do problema do conhecimento, e de seus métodos possíveis, às pressuposiçôes que se situam aquém do registro epistêmico, e o determinam, exige um reposicionamento da questăo dos procedimentos. Algo que Reichelt parece não considerar, quando toma para exame a discussão marxiana da exterioridade do empirismo abstrato para com o objeto de sua análise: "Ainda não trataremos aqui o que se deve entender por 'elos intermediários necessários' nesse contexto; essencial é, muito antes, a indicação de que um método que assume exteriormente as categorias terá de levar a um modo de exposição necessariamente falso do processo global.” (REICHELT, 2013, p. 134). Há que evidenciar aqui duas questóes que surgem de maneira indistinta, as quais se sintetizariam numa única, ao final: 1 - o problema da exterioridade do método se resume nele mesmo? Trata-se de uma questáo determinada unicamente pela gnosiologia pressuposta num método? 2 - Seria a reposição dos contornos da dialética especulativa o único modo eficaz de evitar o mero tangenciamento das determinaçóes categoriais, possibilitando adentrar no âmago das categorias objetivamente existentes? $\mathrm{Ou}$, diversamente, a analítica das formas determinativas não ofereceria ela mesma a possibilidade de identificar sob a regência do concreto e da identificação das relaçóes processuais verificadas o descortino das determinaçóes e das redes relacionais existentes entre as categorias?

Nesse contexto problemático, o papel de referencial, ele mesmo tratado criticamente, desempenhado pelo tema das determinaçóes e mediaçóes trazido e falseado, especulativamente, pelo pensamento de Hegel, parece ser tomado enviesadamente como tema de uma resolução metodológica de cunho lógico. O empírico imediatamente dado, existente e finito pressupóe, para ser como tal, um conjunto de relaçóes historicamente engendradas, de um lado, e, de outro lado, que existem como determinaçóes mais essenciais no processo de produção, mas que não são imediatamente visíveis. Essa delimitação parece remeter direta e necessariamente à démarche hegeliana. No entanto, isto só é verdade parcialmente. Porquanto parta de um entendimento do ser e das categorias como "exato oposto" daquele do de Hegel, Marx de maneira nenhuma nega espessura de realidade concreta a esse empírico como tal, nem muito menos transforma o processo pelo qual o sujeito concreto - vivo e ativo - conhece em processo de dação de realidade. A cognição se apossa do efetivo como processo de síntese, exatamente porque aquele o é na realidade 
imediata, não obstante não se possa no nível da prática direta, da intuição e da representação compreendê-lo em sua rede de determinaçóes. A existência imediata da totalidade de elementos e relações efetivas é o pressuposto objetivo da própria tematização, uma pressuposição ela mesma atualidade finita, advinda processualmente no decurso histórico, de todo diferente de uma eternidade natural ou de um puro dado da intuição e da representação a ser medido e manipulado subjetivamente.

É possível reconhecer uma tríade temática no pensamento marxiano composta de processualidade histórica na qual se engendraram formas de vida socialmente determinadas, de finitude atual objetivamente determinada, mas tão somente capturada na experiência imediata como datidade existencial, e por fim, de apreensão categorial, resultado dos passos de uma viagem cognitiva que se eleva da empiricidade abstrata à concretude compreendida pelo pensamento a ser reproduzida no corpo de uma teoria. Esses três elementos perceptíveis no exame da tematização marxiana dos economistas é convertida quase que kantianamente numa relação entre dois extremos. De um lado, a facticidade histórica decorrida como pressuposto de um existente dado e, de outro lado, a cientificidade exercitada ao modo de um construto lógico de termos, cujas conexóes não necessariamente se referenciariam pela efetividade do que se enfrenta cognitivamente, mas antes decorreriam de uma "leitura" que incorpora as abstraçôes pela matriz epistemológica da contradição. O caminho de apreensão objetiva de nexos igualmente objetivos efetivamente existentes estaria vedado à teoria. A crítica marxiana à indeterminação categorial dos economistas teria por corolário necessário a conformação de um método expositivo o qual se situaria do ponto de vista da articulação procedimental para com as categorias. Por conseguinte, Marx teria produzido, sob inspiração hegeliana, uma composição lógica de interpenetração categorial, uma dialética conceitual das categorias do capital, quando, em verdade, o que se encontra consignado já desde 1857 é exatamente a objeção com relação a isto, como encadeamento possível porém superficial: "Dies ist allerdings ein Zusammenhang, aber ein flacher” (MARX, 1983, p. 25).

Dessa maneira, os "seus limites", da forma dialética da exposição, estabelecem-se na exata medida em que se reconheça a náo coincidência entre os processos de efetivação do concreto e aquele outro pelo qual der Kopf se apodera conceitualmente dele. A exposição tem sua validade conferida não em virtude de uma norma de coerência interna, mas sim de sua correspondência conceitual para com o complexo categorial que existe como ente/processo 
independentemente do pensamento. $\mathrm{O}$ modo como as categorias se interpenetram e interdeterminam deve ser exposto como articulação categorial pensada. Como "intuição" teórica da identidade/não-identidade das categorias, da elaboração conceitual dos movimentos de diferenciação processual, a dialética hegeliana pode, em termos gerais (e somente como generalidade formal, nunca como conteúdo determinativo), fornecer certos elementos úteis à construçáo daquela apresentação da articulação das categorias, o que é aferido novamente como uma suposta relação transcorrida apenas entre dois registros:

[...] a existência de um conjunto de trabalhadores assalariados livres constitui o pressuposto para a elaboraçáo conceitual do sistema capitalista global na forma da exposiçáo dialética das categorias, mas que essa forma de exposição, por seu turno, não é imediatamente idêntica à reconstituição da gênese histórica do capital e do trabalho assalariado livre. Essa diferenciação entre a sequência lógica das categorias e a gênese histórica do capitalismo náo se encontra na obra inicial, como vimos. E verdade que também ali se ressalta claramente que só com a separação completa entre a existência subjetiva e as condições objetivas de sua realização torna-se possível vislumbrar a estrutura da história, mas naquela época ele náo conseguiu chegar à formulaçáo teórica do curso real da história. (REICHELT, 2013, p. 139).

Frente a isso, é necessário assinalar que, se essa conexão existe, ela não se situa no registro delimitado pelo enfrentamento lógico do decurso histórico. Marx afirma exatamente a não homologia entre a exposição das categorias, que parte da relação como dado e da pressuposição de todo um processo histórico que na realidade a engendrou socialmente. $\mathrm{O}$ processo histórico constitui um pressuposto factual da existência atual do capital, mas não significa que ele seja reposto continuamente sob forma idêntica, por exemplo, dos cercamentos e expulsão dos camponeses livres do Renascimento. Náo se trata de uma sequência lógica num sentido estrito, mas da exposição de uma "lógica" específica de um tipo de existência social atual de caráter finito, ou seja, que possui uma determinação particular, uma differentia specifica central, se comparada às demais épocas ou formaçóes societárias. A descrição "lógica" da efetividade seria o resultado da abstração das contingências do desenvolvimento histórico empiricamente vivido e constatável. Em parte, as abstraçóes razoáveis têm esse caráter. Todavia, apenas em parte. Estas náo possuem em si a virtualidade de encaminhar a resolução do conhecer. Somente participam positivamente no interior de um roteiro que assinale e ponha em evidência a distinção que determina o existente em sua particularidade. 
Tal não significa a dispensa da compreensão histórica in limine, pois, por um lado, a descrição histórica auxilia na compreensão do processo de constituição que desaguou na efetivação de uma dada configuração social da produção, no modo particular das categorias. Marx assevera que a explicação científica da atualidade categorial da produção não se identifica a isso, não obstante disso necessite, na medida em que permite capturar o modo peculiar pelo qual os pressupostos da produção do mais-valor devieram a ser o que são. No entanto, este ser náo necessariamente coincide com seu processo de vir a ser, com a história em prazo amplíssimo das categorias, nem é este de ordem genealógica. A história das categorias é, ao contrário, a história real de como estas são, ou podem ser, a cada momento, diferentes em seus modos de existir e de viger nos diferentes modos possíveis de produzir a vida humana. Veja-se o exemplo que Marx dá acerca do dinheiro, na Introdução de 1857. Já o esclarecimento da existência atual da categoria remete à compreensão da sua presença como elemento estruturante e estrutural, numa determinada e particular articulação concreta e atual da produção, seu papel, ora determinante ora determinado, dentro da arquitetônica que define a vertebração específica de uma dada modalidade da produção social da vida humana. Não se trata de uma armação "lógica", ainda que adote por necessidade discursiva a aparência de tal esquema, mas sim da descrição da ontologia da produção da vida humana, num momento preciso e circunscrito, ocidental, moderno, à diferença dos demais, a figuração da articulação das formas de ser que perfazem o capital como uma plenitude categorial, tanto "dada" na forma da efetividade, objetivamente, quanto em sua reprodução pesquisada e exposta na forma do pensamento. Assim, não parece se tratar, ao menos num plano prioritário, de uma relação epistêmica entre o histórico e o "lógico", concebidos já como âmbitos filtrados no recesso da cognição, mas entre a efetividade social objetiva, em seus planos de constituição e de constituído, e a apropriação científica desta como articulação pensada de uma articulação real que veio a ser e é o que é.

O sentido do problema de uma aproximação parametrizada pela necessidade duma conformaçáo lógica pode ser especialmente aferida quando Reichelt toma para exame a categoria capital e se propóe definir seu estatuto conceitual. É importante, contudo, deixar ressaltado que o autor alemão atina de modo pertinente para a existência de uma totalidade real - o trabalho social total como capital - que delimitaria o conjunto da produção, embora sob a forma de um espargimento dos trabalhos, sua divisão social:

Em si os múltiplos objetos são produtos do trabalho social global que se decompóe numa totalidade de ramos específicos de trabalho. Porém - e 
isso é essencial —, eles não aparecem como tais. De modo imediato os produtos são meramente coisas concretas de uso, produtos do trabalho individual, que não aparentam ser parte de uma unidade; que uma parte do trabalho social global foi despendida para sua confecção. Mas caso se pretenda repartir o tempo de trabalho que está à disposição da sociedade global pelos diferentes ramos de produção, tendo como parâmetro determinadas estruturas de necessidade, isso só será possível se os diferentes produtos se manifestarem como expressóes quantitativamente diferentes da mesma unidade. Essa é a ideia-chave da teoria marxiana do valor e do dinheiro (REICHELT, 2013, p. 153).

Ou seja, a produção é sempre um ato socialmente determinado, expressado na diversidade de modos de distribuição e repartição dos produtos. Não se trata de distribuir "bens" provenientes de uma atividade determinada por alguma lei natural, mas de suprir carecimentos objetivos sob formas diferentes e condicionadas pela determinação social particular da produção. O capital é, como controle social, o modo de aparecer da unidade determinada da totalidade orgânica, baseada na alienação da potência criadora, ao mesmo tempo, de valor de uso e valor (e, dentro dele, de mais-valor). O valor das mercadorias é uma expressão da unidade que perfaz a totalidade espargida da produção/ circulação, a de serem produtos da criação de riqueza como capital, como entes cuja determinação principal de existência tem de ser continuamente reengendrada num patamar cada vez mais elevado que o anterior: o valor deve ser valorizado, a produção reproduzida, o dinheiro capitalizado.

Uma vez feita essa ressalva, é necessário discutir o modo como Reichelt entende a assimilação teórica dessa totalidade. Porquanto Marx se coloque frontalmente crítico à especulatividade hegeliana, à dúplice pressuposição da lógica como ontologia, de supor a imanência do esquema como princípio da realidade e da afirmação da transparência total pela via da identidade sujeito-objeto, parece restar então unicamente a possibilidade da atribuição lógico-epistemológico como procedimento de tratamento de um finito dado, resultante de um decurso histórico, mas ele por si mesmo absolutamente intransparente ao entendimento. A afirmação da existência da totalidade da produçáo parece possuir, por isso, validez apenas epistêmica, de maneira nenhuma encontrando arrimo na concretude existente, no Dasein da produção do capital. Seria, por conseguinte, "ideia-chave da teoria". Esse caráter problemático pode ser observado no modo como o autor expóe o desenvolvimento elucidativo da forma valor, na relação entre as mercadorias: 
[...] como as diferentes formas naturais de cada uma dessas mercadorias são apenas formas equivalentes específicas ao lado de outras, os muitos trabalhos sensíveis concretos são tidos como outras tantas formas de manifestação específicas do trabalho humano. Só existem, portanto, formas equivalentes específicas, cada uma das quais exclui a outra, cada uma sendo forma equivalente limitada. Assim sendo, o valor de uma mercadoria possui forma total de manifestação na totalidade de todas as formas de manifestação específica, mas essa forma de manifestação não é uma forma unitária. Contudo, ao expressar o seu valor na totalidade de todas as demais mercadorias, a própria mercadoria se converte em forma de manifestação do valor de todas essas mercadorias. Desse modo, o problema está simultaneamente resolvido. Visto que todas as mercadorias expressam o seu valor de modo simples (num só corpo da mercadoria) e de modo unitário (no mesmo outro corpo da mercadoria), elas também se apresentam umas para as outras como expressóes específicas da mesma substância. Mediante a sua igualdade com a forma natural de determinada mercadoria, cada mercadoria individual expressa o seu valor não só numa forma unitária, diferente do seu valor de uso, mas simultaneamente também como aquilo que ela possui em comum com todas as mercadorias. Somente agora o valor adquire uma forma diferente de sua forma natural, cuja universalidade corresponde à do conceito de valor. (REICHELT, 2013, p. 164).

A démarche de uma conexão proporcional (Verhältnis) aparece claramente e, tanto na prática imediata quanto no processo metabólico total do valor valorizado, as mercadorias se apresentam reciprocamente nessa validade, a qual se afirma como uma Denkensform que desempenha uma função efetiva no processo de produção, como integrante do momento da circulação das mercadorias e de realização do mais-valor. Marx frequentemente usa o verbo gelten - mais ou menos valer como ou passar por - para designar esse tipo de relação, modo pragmático e manipulatório que aponta, não obstante de maneira invertida, para a vigência real de uma abstração efetiva. É uma abstratividade do valor valorizado que adquire como capital em geral a concretude de uma determinação de existência sobejamente preponderante. Por conseguinte, um conceito que, epistemologicamente, corresponde a uma determinação real da forma mercadoria de ser dos produtos do trabalho humano que deve ser desenvolvida no processo social até adquirir uma figuração acabada. Enquanto o conceito em Hegel é a existência como tal da coisa em sua efetividade da qual o existente atual seria uma realização incompleta ou finita, em Marx, o existente atual contém mais que o conceito, o conceito é uma amálgama de aspectos gerais que se observam no existente atual, mas que não o "explicam" nem estão nele "implicados" (num sentido panteísta, como o da Lógica). A estrutura da atualidade das categorias, segundo a determinação histórico-social 
particular, tem como ponto central a sua faceta específica que a faz elemento de um dado modo peculiar de produçáo da vida. $\mathrm{O}$ conceito náo tem, como na especulação, uma espessura ontológica análoga ao existente atual, existindo apenas como categoria do e no existente atual.

Essa virtualidade é já observada na própria forma dinheiro, modo de ser do valor como efetividade figurada autonomamente ao lado das mercadorias: "Uma mercadoria específica se converte no 'conceito do valor de todas as coisas", conforme assevera Marx, nos escritos iniciais; “[...] o próprio universal dos produtos específicos do trabalho ainda existe numa forma específica." (REICHELT, 2013, p. 165). A correspondência para com seu conceito que é reconhecida e ressaltada pelo estudioso alemão não possui, porém, a mesma tessitura que no interior da Lógica, mas antes toma, por assim dizer, de empréstimo por analogia, o sentido de necessidade categorial nela fixado. $\mathrm{O}$ que aparece na exposição como produto de um movimento de síntese orientado por uma necessidade conceitual férrea parece antes, a Marx, como resultado real da constituição e fixação de padrôes de reprodução social. Nesse sentido, a transformação do valor em capital não é um telos dado pelo, e no, desenvolvimento autônomo da Ideia. Possui ao contrário o estatuto de um roteiro cumprido todos os dias pelo dinheiro, ou pelos dinheiros, que efetivamente se realiza como capital no processo social. A determinação do capital como valor que se valoriza por meio da processualidade social da produção é o modo de ser da riqueza, uma Daseinsform real, que se observa pela análise das determinações da produção existente de forma finita.

O universal se estabelece como coisa, mas somente porquanto seja in fact uma coisa frente às demais, funcionando como uma coisa, um existente atual econômico, uma mercadoria. Na verdade, marxianamente, o processo é antes o inverso, na relaçáo das figuras mercantis; uma delas assume no processo social a função de exibir no seu Korps, na sua efetividade finita, a determinação essencial social da mercadoria. Por isso, o conjunto das relaçóes de troca aparece como uma necessidade interna ao processo de valorização, porque, no seu decorrer, venha à luz a articulação categorial contraditória sob o mando da qual é ela produzida e controlada em sua circulação.

No entanto, dada a conformação inicial em que a própria questão estatutária das categorias é levantada, no interior de uma inquirição epistêmica que se resolveria na medida em que se desvelasse a contextura lógica do conceito. A logicidade da operaçáo tomada como centro da cientificidade 
pode fazer inclusive que se torne a "lógica" da relação imediata momento preponderante, quando ele nada mais é que Ausdruckt:

A mercadoria adquire mediante o ato de equiparaçáo uma forma de valor
distinta de sua forma natural; uma outra mercadoria é tida, em sua forma
natural imediata, como forma de manifestaçáo de "geleia de trabalho humano
indiferenciado". O problema foi reduzido agora à mera pergunta se a forma de
valor corresponde à universalidade do conceito de valor, isto é, se é uma forma
em que todas as mercadorias se apresentam umas às outras como expressóes
reificadas da mesma substância. (REICHELT, 2013, p. 163).

Adquire ou, antes, revela? Pois o processo de produção de trabalho é ele mesmo empreendido como processo de valorização. A relação das mercadorias entre si não as transforma em mercadorias, mas realiza sua determinação de serem produzidas como capital, como parte integrante da produção capitalista, cuja meta primeira é o engendramento do mais-valor. A equiparação na troca é uma Erscheinungsform do capital, o modo de aparecer o valor e o mais-valor, produzidos em ato pelo valor de uso formal da força de trabalho. Expressão abstrata de uma para outra, que, aliás, não acontece empiricamente, porém, é uma expressão abstrata ou uma abstração razoável das trocas múltiplas e multilaterais da circulação. Possivelmente Reichelt, e não somente ele como também toda uma tradição de abordagens, leia a exposição abstrata das multilateralidade dos intercâmbios, arrimada na identificação de formas abstratas que razoavelmente fixam as demarcaçóes mais comuns e aquelas igualmente mais determinantes, como o recurso a uma lógica antitética de termos neutros. Nesse caso, o processo de troca não é um resultado ocasional da expansão da produção, mas é um elemento essencial à reprodução continuada do processo de valorização, o equivalente universal é incorporado por uma mercadoria cujas propriedades objetivas reais atendem às exigências de mediação da realização do valor valorizado na circulação.

O não entendimento da relação cognitiva que parte da efetividade como datidade caótica à sua apreensão no nível da totalidade de concreto pensado, como processo de conhecer que está arrimado no reconhecimento do próprio efetivo dado à intuição e à representação, para aquém delas, como totalidade já ordenada, acaba por requerer a identificação de um caráter necessariamente lógico que subjazeria ao discurso como norma. A desconsideração para com o ponto de honra para a cientificidade marxiana, da determinaçáo do ser por si, do existente como plenitude categorial, a ontológica pressuposição da validade categorial é decisiva para o descaminho do entendimento da teoria em pura forma lógica. Esse tipo de aproximação 
faz com que se atenue o peso objetivo da determinação exposta e se desfaça qualquer possibilidade de liame real entre o conceitual e o existente. Assim, os passos da cientificidade se resumem a passos formais, na acepçáo de um procedimento autossustentado, suportado e fundamentado unicamente por suas virtude internas. Constitui uma forma de colocar o problema que pode ser evidenciada já na estrutura da própria argumentação:

A análise da mercadoria como unidade de valor de uso e valor de troca resultou em que ela deve tornar-se ambos os valores, sendo que a realização de um está reciprocamente vinculada à realizaçáo do outro, mas a realização de um ao mesmo tempo exclui a realização do outro. A única solução possível para esse círculo vicioso de problemas está em fazer com que o metabolismo social seja mediado por uma mudança de forma da mercadoria, efetuando-se, por assim dizer, em dois passos: a mercadoria se realiza como valor de uso ao assumir uma forma de existência social diferente de sua forma natural imediata, ao adquirir uma forma na qual ela é tida pelas outras mercadorias como encarnação imediata do trabalho abstratamente universal, e então substitui, enquanto equivalente, uma quantidade arbitrariamente determinada de qualquer outra mercadoria. (REICHELT, 2013, p. 188).

A existência mesma da forma mercadoria como unidade sintética é apresentada como fruto da analítica; quanto à forma de ser mercadoria dos produtos do trabalho, é ela mesma forma do concreto que, isso sim, é desmembrada analiticamente em suas determinaçóes, por sinal, antitéticas. Os passos procedimentais não se justificam autonomamente, contudo, são requeridos pelo modo peculiar e objetivo de articulação que as categorias apresentam na finitude do modo de produção. Por isso, é uma contradição em processo, na medida em que o valor náo é um ente com um dadidade, mas uma determinação da forma de ser que se concretiza no circuito da valorização da produção à circulação. Isso indica ademais o caráter objetivo do processo, não se reduzindo este a qualquer das variáveis de natureza subjetiva ou ideal, tais como "expectativas dos agentes", "apostas racionais", "precificação" etc.; antes, essas são Gedankensformen correspondentes às formas particulares de existência do capital, em seus diferentes momentos de realização.

A vigência do reconhecimento da dignidade ontológica do existente no interior da atividade científica possibilita superar, no concreto pensado, a ordem de aparecer empírico das categorias. Por exemplo, o capital é o pressuposto determinativo da mercadoria e não o contrário, ainda que esta seja uma forma necessária de realizaçáo daquele, no circuito da produção à reprodução, antecedendo-o historicamente, e aquele tenha na mercadoria 
sua forma necessária de aparição. Essa totalidade articulada é expressa, e não engendrada, conceitualmente. A cientificidade não tem sua matriz no exercício de um método. Por esse motivo, Marx utiliza, ao invés da imagem de um sistema de categorias, aquela da totalidade orgânica, necessariamente aberta e cuja dinamicidade não está inscrita nos limites da autorrealização de um princípio, mas do engendramento do princípio como tal da produção, no curso mesmo da constituição do humano. $\mathrm{O}$ concreto tal qual é não se reveste para Marx de um sentido meramente empírico, imediato, porém é, ao contrário, um feixe de categorias, dado que o pensar como atividade social e objetivamente determinada busca apreender e explicar.

Aqui, a "similaridade" é somente aparência, porquanto a delimitação do ser da coisa é diametralmente oposta àquela da Especulaçáo. Por conseguinte, a crítica a Hegel possui um caráter ontológico, situado aquém do terreno epistêmico e mesmo gnosiológico. O ser atual, tal qual ele é, em sua finitude, possui dignidade ontológica própria. A relação mesma entre o "lógico" (concebido racionalmente como reprodução conceitual) e o existente não é delimitada pelos cânones da filosofia transcendental kantiana. Por conta disso, a "logicidade imanente" somente se pode entender pela necessidade de explicar como se deu a produção num sentido cronológico e originário de certa pressuposição (a existência do trabalhador que empenha força de trabalho), a qual se fixa como um dos pilares categoriais reais - e não apenas, e menos ainda primeiramente, da teoria - que tornam a produção do mais-valor um dado modo específico da produçáo da vida humana, em comparação, por differentia specifica, para com outros modos de interatividade social. Entretanto, se o termo logicidade remete a um esquema prévio, no qual as contradiçôes aparecem e determinam processos como formas lógicas de uma perspectiva teórica, parece bastante inadequado, sobretudo, tendo-se em vista as observaçóes marxianas que abundam nos Grundrisse e indicam que a dialeticidade formal a priori do encadeamento (como simples dialética de conceitos) é apenas uma aparência discursiva da exposição, cabendo a esta última apresentar a articulaçáo categorial real, torná-la apreensível cognitivamente. 
ALVES, Antônio Jose Lopes Alves. Value and its forms in the Marxian critique of political economy. Trans/form/ação, Marília, v. 39, n. 1, p. 159-212, Jan./Mar., 2016.

\begin{abstract}
The present article aims to present and explain the theoretical status of the Marxian category of value, as determined in the context of the critique of political economy in its mature phase (1857-1881). In particular, it discusses how Marx presents the relationship of categorical determination of value with other relationships that compose and constitute the commodity form of the products of human labor. In this sense, the Marxian theory of value appears as a critical exposition of the capitalist mode of production, based on the categorical analysis of the commodity and aiming to reveal it in its most essential dimension: as the vehicle for implementing the appreciation of value. Value, according to the development of the Marxian argument in the Grundrisse and the Capital, is analyzed in its configuration as a determination process that unfolds, presupposes, and implies a set of other formen. These are articulated in moments of real differentiation and development that are concretely expressed in objectifications human labor existing as moments of capital. Goods, market, and capital lose all their appearance as the reciprocal externality of "stuff", to reveal realizations of a socio-historical mode of producing human life.
\end{abstract}

KEYWORDS: Marx, Critique of Political Economy, value, capital, category.

\title{
REFERÊNCIAS
}

ALVES, A. J. L. Differentia specifica e determinação formal na obra marxiana da maturidade. Verinotio, Belo Horizonte, v. 13, p. 101-109, 2012.

. Modos e formas: dimensôes filosóficas da crítica marxiana da economia política. Kriterion, UFMG, v. 127, p. 125-140, 2013.

. O Marxismo Hegeliano e a nova leitura dialética da obra de Marx. Princípios, v. 20, p. 125-156, 2014.

CHASIN, J. Marx: estatuto ontológico e resolução metodológica. São Paulo: Boitempo, 2009.

MARX, K. Das Kapital, erster Buch - Kritik der politischen Ökonomie, In: Marx-Engels Werke, Band 23. Berlin: Dietz, 1998.

. Grundrisse der Kritik der politischen Ökonomie, In: Marx-Engels Werke, Band 42. Berlin: Dietz, 1983.

. Randglossen zu Adolph Wagners "Lehrbuch der politischen Ökonomie“. In: MarxEngels Werke, Band 19. Berlin: Dietz, 1962.

MARX, K.; ENGELS, F. Die deutsche Ideologie, In: Marx-Engels Werke, Band 3. Berlin: Dietz, 1969.

MÜLLER, M. L. Exposição e método dialético em "O Capital". Boletim SEAF, n. 2, p. 17-41, 1982.

NAPOLEONI, C. Smith, Ricardo, Marx. Rio de Janeiro: Graal, 2000. 
ALVES, A. J. L.

REICHELT, H. Sobre a estrutura lógica do conceito de capital. Campinas: Editora Unicamp, 2013.

ROSDOLSKY, R. The making of Marx's Capita". London: Pluto, 1977.

VAISMAN, E. Dossiê Marx: itinerário de um grupo de pesquisa, In Ensaios Ad Hominem. São Paulo: Estudos e Ediçóes Ad Hominem, 2001. Tomo IV. p. I-XXIX.

Recebido em 18/10/2015

Aceito em 15/11/2015 